\title{
Minireview
}

\section{Analgesia with Gabapentin and Pregabalin May Involve N-Methyl-D-Aspartate Receptors, Neurexins, and Thrombospondins}

\author{
Charles P. Taylor and Eric W. Harris \\ CP Taylor Consulting, Chelsea, Michigan (C.P.T.) and Cambrium Group, Raleigh, North Carolina (E.W.H.) \\ Received March 2, 2020; accepted April 17, 2020
}

\begin{abstract}
The gabapentinoid drugs gabapentin and pregabalin (Neurontin and Lyrica) are mainstay treatments for neuropathic pain and preventing focal seizures. Both drugs have similar effects to each other in animal models and clinically. Studies have shown that a protein first identified as an auxiliary subunit of voltage-gated calcium channels (the $\alpha_{2} \delta$-subunit type 1 [ $\alpha_{2} \delta$-1], or Cava2d1 ) is the high-affinity binding site for gabapentin and pregabalin and is required for the efficacy of these drugs. The $\alpha_{2} \delta-1$ protein is required for the ability of gabapentin and pregabalin to reduce neurotransmitter release in neuronal tissue, consistent with a therapeutic mechanism of action via voltage-gated calcium channels. However, recent studies have revealed that $\alpha_{2} \delta-1$ interacts with several proteins in addition to voltage-gated calcium channels, and these additional proteins could be involved in gabapentinoid pharmacology. Furthermore, gabapentin and pregabalin have been shown to modify the action of
\end{abstract}

a subset of $N$-methyl-D-aspartate-sensitive glutamate receptors, neurexin- $1 \alpha$, and thrombospondin proteins by binding to $\alpha_{2} \delta-1$. Thus, these effects may contribute substantially to gabapentinoid therapeutic mechanism of action.

\section{SIGNIFICANCE STATEMENT}

It is widely believed that gabapentin and pregabalin act by modestly reducing the membrane localization and activation of voltage-gated calcium channels at synaptic endings in spinal cord and neocortex via binding to the $\alpha_{2} \delta$-1 protein. However, recent findings show that the $\alpha_{2} \delta$-1 protein also interacts with $N$-methyl-D-aspartate-sensitive glutamate receptors, neurexin$1 \alpha$, thrombospondins (adhesion molecules), and other presynaptic proteins. These newly discovered interactions, in addition to actions at calcium channels, may be important mediators of gabapentin and pregabalin therapeutic effects.

\section{Introduction}

The amino acid drugs gabapentin (Neurontin) and pregabalin (Lyrica) are mainstay treatments for neuropathic pain from diabetic neuropathy, postherpetic neuralgia, or spinal cord injury. In animal models [reviewed in Tuchman et al. (2010)] and clinical trials, gabapentinoid drugs reduce several kinds of chronic, neuropathic, and postsurgical pain for a short period after dosing. In addition, if given throughout injury, they reduce subsequent long-lasting pain in animal models (Field et al., 1997) and are often used during surgery to reduce long-lasting pain and opiate use (Buvanendran et al., 2010;

C.P.T. previously was employed and owned stock in Pfizer, Inc., but no longer has financial conflicts. E.W.H. claims no conflicts.

https://doi.org/10.1124/jpet.120.266056.
Clarke et al., 2012). They are also approved for preventing focal seizures of epilepsy, and pregabalin is approved for fibromyalgia and for generalized anxiety disorder (in the European Union). Gabapentin and pregabalin are similar structurally, pharmacologically, and in side effect profile but differ in the extent of oral absorption. Because gabapentin is a structural derivative of GABA (the primary inhibitory neurotransmitter), the United States Adopted Names Council chose the name "gabapentin." However, this does not indicate its mechanism: gabapentin and pregabalin are essentially inert at GABA receptors and synapses [reviewed in Taylor et al. (2007); Taylor (2009); Dolphin (2016)]. Recently, a third, gabapentinoid compound, mirogabalin, has been studied (Domon et al., 2018). All three drugs bind with high affinity and specificity to a membrane-bound protein originally identified as an auxiliary subunit of voltage-gated calcium

ABBREVIATIONS: $\alpha_{2} \delta$-1, $\alpha_{2} \delta$-subunit type 1; Cache domain, extracellular calcium channels and chemotaxis receptor domain; CaV, Voltage-gated calcium channel (IUPHAR nomenclature); CaVa2d1, voltage-gated calcium channel subunit $\alpha_{2 \delta^{-1}}$ (IUPHAR nomenclature); FRET, fluorescent resonance energy transfer; GPI anchor, glycosylphosphatidylinositol anchor; LRP1, low-density lipoprotein receptor-related protein-1; LTP, long-term potentiation; mEPSC, miniature excitatory synaptic current; MIDAS, metal ion-dependent adhesion site (common to von Willebrand domain proteins); NMDA, N-methyl-D-aspartate; NMDA receptor, NMDA-sensitive glutamate receptor; RAP, GTP binding Ras-related protein; Rac1, Ras-related C3 botulinum toxin substrate 1; VWA, von Willebrand A. 
channels. The $\alpha_{2} \delta$ - 1 and $\alpha_{2} \delta$-2 isoforms (coded by CACNA2D1 and -2 genes) mediate high-affinity binding of both gabapentin and pregabalin in forebrain and spinal cord (Gee et al., 1996; Bian et al., 2006). Recently, a cryo-electron microscope study of purified rabbit skeletal muscle calcium channels (Wu et al., 2016) enabled a high-resolution model (Kotev et al., 2018) showing $\alpha_{2} \delta$-1 with a bound drug molecule (Fig. 1). An artificial alanine substitution for the arginine residue at $\alpha_{2} \delta$ 1 position 217 (R217A) greatly reduces drug binding (Wang et al., 1999) and also reduces gabapentinoid analgesic (Field et al., 2006), anxiolytic-like (Lotarski et al., 2011), and anticonvulsant actions (Lotarski et al., 2014) in mouse models. In contrast, the actions of non- $\alpha_{2} \delta$ - 1 drugs were spared.

Although $\alpha_{2} \delta$-2 also binds gabapentin and pregabalin with high affinity, this apparently does not contribute to most clinical pharmacology, since mutations that reduce drug binding to $\alpha_{2} \delta-2$ failed to alter gabapentinoid anxiolytic-like or anticonvulsant action in mice and did not alter drug effects on glutamate release (Lotarski et al., 2011, 2014; Quintero et al., 2011). Although analgesic effects of gabapentinoid drugs have not been tested in $\alpha_{2} \delta$-2 mutant mice, findings to date suggest that $\alpha_{2} \delta-2$ does not contribute much to gabapentinoid analgesia (e.g., Field et al., 2006), and $\alpha_{2} \delta$-1 is now widely accepted as the key to gabapentin and pregabalin drug actions for analgesia, anxiolytic action, and seizure prevention. One exception shows a notable drug effect that has been attributed to action at $\alpha_{2} \delta-2$ : a recent study shows that gabapentin acts at $\alpha_{2} \delta-2$ to increase corticospinal plasticity and regeneration after spinal cord injury in mice (Sun et al., 2020). This study also shows enhanced behavioral recovery, but to date, it is not known what other cellular proteins might interact with $\alpha_{2} \delta$-2 to stimulate growth cones and the formation of new corticospinal connections. These findings suggest that chronic treatment with gabapentinoid drugs (acting at $\alpha_{2} \delta-2$ ) could enhance recovery after spinal cord injury. Furthermore, Obermair and colleagues (Geisler et al., 2019) showed that presynaptic overexpression or ablation of one splice variant of $\alpha_{2} \delta-2$ altered the postsynaptic localization of $\mathrm{GABA}_{\mathrm{A}}$ receptors in cultured hippocampal neurons. Although these findings are fascinating, they may not relate directly to gabapentinoid analgesia, so the rest of our review will focus on $\alpha_{2} \delta$-1. It also should be noted that $\alpha_{2} \delta-2, \alpha_{2} \delta$-3, and $\alpha_{2} \delta$-4 provide important biologic functions to interact with calcium channels in various anatomic areas (e.g., Davies et al., 2006) [reviewed in Dolphin (2013, 2016, 2018)].

The $\alpha_{2} \delta$-1 protein binds directly to the calcium channel pore protein, $\alpha_{1}$ or $\mathrm{Ca}_{\mathrm{V}} \alpha 1$ (Fig. 1; Table 1). This modifies both the kinetic properties (Welling et al., 1993; Gurnett et al., 1996) and cellular localization (Heblich et al., 2008; Hendrich et al., 2008; Kadurin et al., 2016) of calcium channels [reviewed in Heblich et al. (2008), Hendrich et al. (2008), Zamponi et al. (2015)]. Most investigators conclude that gabapentinoid analgesia derives from reducing the excitability of neuron networks by reduced numbers of functional calcium channels and subtly modulated functional properties. However, the molecular details of reduced transmitter release caused by gabapentinoids [reviewed in Dooley et al. (2007)] have not been clear.

In addition to its role as a subunit of voltage-gated calcium channels, $\alpha_{2} \delta-1$ acts as a cell adhesion molecule with structural homologies to integrins (Pan et al., 2016b) that also contain a von Willebrand A (VWA) domain with a metal ion-dependent adhesion site (MIDAS) (see Fig. 1). The VWA domains of integrins bind to extracellular matrix proteins and deliver signals to the cytosol and also change conformation in response to cellular signals (Ginsberg et al., 2005; e.g., Li et al., 2017). The VWA domain of $\alpha_{2} \delta$-1 mediates the interaction between $\alpha_{2} \delta$-1 and calcium channels (Canti et al., 2005). In a
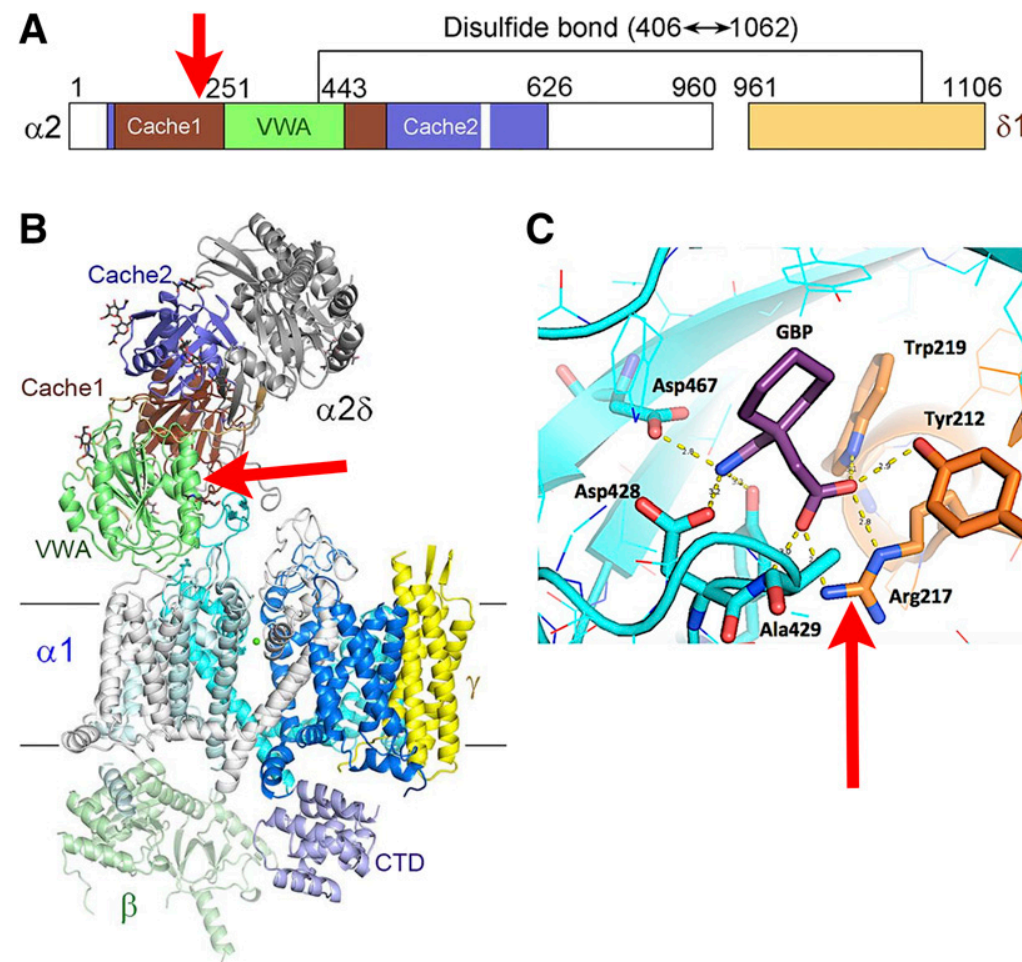

Fig. 1. Structures of the $\alpha_{2} \delta-1$ protein based on cryoelectron microscopy and molecular modeling (Wu et al., 2016) of calcium channels purified from skeletal muscle. (A) The numbered $\alpha_{2} \delta$-1 sequence with major domains colored [as in (B)]. The immature $\alpha_{2} \delta$-1 protein is cleaved (between residue 960 and 961), and the two resulting segments are joined by a disulfide bridge. The arginine at position 217 (Arg217) is critical for drug binding (see text) and is shown with a red arrow in each subpart of the figure. (B) Atomic resolution map of the entire voltage-gated calcium channel protein, including the ion-conducting $\alpha_{1}$ subunit (white and shades of blue for the four transmembrane domains), the $\gamma$ subunit (yellow, which is not found in brain calcium channels), and the $\beta$ subunit (pale green, on the cytosolic side of the membrane). The $\alpha_{2} \delta$-1 protein includes the VWA (green) with a MIDAS, Cache 1 and Cache 2 (brown and purple), and the C-terminal domain (CTD, purplish-gray). Some of the polysaccharide (glycan) groups are shown as abbreviated stick-figure sugar molecules. The R217 residue (red arrow) is buried in the middle of the protein between the VWA domain and the Cache 1 domain. (C) The presumed drug binding pocket (Kotev et al., 2018) consists in part of the Arg217 residue (red arrow), which coordinates with the acid moiety of gabapentin (GBP, purple). Other residues (numbered) coordinate with both the acid and the amine of gabapentin. It is presumed that drug binding to this pocket causes a large conformational change to $\alpha_{2} \delta-1$ that alters its interaction with other proteins. Figures are adapted from Wu et al. (2016) [parts (A) and (B)] with permission from AAAS and from Kotev et al. (2018) [part (C)], with permission from Journal of Chemical Information and Modeling, copyright (2016) American Chemical Society. 
TABLE 1

Proteins interacting directly with $\alpha_{2} \delta-1$

\begin{tabular}{|c|c|c|c|c|c|c|}
\hline Target Protein & $\begin{array}{l}\text { Target Protein } \\
\text { Region }\end{array}$ & $\alpha_{2} \delta-1$ Region & Experimental Method & $\begin{array}{c}\text { Effect of } \alpha_{2} \delta-1 \text { on } \\
\text { Target }\end{array}$ & $\begin{array}{l}\text { GBP or PGB Drug } \\
\text { Effect }\end{array}$ & Reference \\
\hline $\begin{array}{l}\text { Ca channel } \alpha_{1} \\
\text { subunit }\left(\mathrm{Ca}_{\mathrm{v}} 1\right. \\
\text { and } \mathrm{Ca}_{\mathrm{V}} 2 \text {, but } \\
\left.\text { not } \mathrm{Ca}_{\mathrm{v}} 3\right)\end{array}$ & $\begin{array}{l}\text { Extracellular part } \\
\text { of domain III } \\
\text { (??) }\end{array}$ & $\begin{array}{l}\text { VWF-A domain } \\
\text { MIDAS }\end{array}$ & $\begin{array}{l}\text { Coisolation with } \\
\text { solubilized protein } \\
\text { purification }\end{array}$ & $\begin{array}{l}\uparrow \text { Ca channel } \\
\text { membrane } \\
\text { stability; alters } \\
\text { Ca channel } \\
\text { kinetics }\end{array}$ & $\begin{array}{c}\downarrow \text { Ca channel } \\
\text { number at } \\
\text { membrane }\end{array}$ & $\begin{array}{l}\text { Felix et al., 1997; } \\
\text { Canti et al., } \\
2005\end{array}$ \\
\hline $\begin{array}{l}\text { Ca channel } \alpha_{1} \\
\text { subunit }\left(\mathrm{Ca}_{\mathrm{V}} 1.1\right) \\
\text { (skeletal muscle) }\end{array}$ & $\begin{array}{c}\text { Extracellular part } \\
\text { of domain III } \\
\text { loop 5, domain I } \\
\text { loop 5, and } \\
\text { domain II loop 5 }\end{array}$ & $\begin{array}{l}\text { VWF-A domain } \\
\text { and Cache } 1 \\
\text { domain }\end{array}$ & $\begin{array}{l}\text { Cryo-electron microscopy } \\
\text { with molecular } \\
\text { modeling of } \alpha_{1} \text { and } \\
\alpha_{2} \delta-1\end{array}$ & & & $\begin{array}{r}\text { Briot et al., 2016; } \\
\text { Wu et al., } 2016\end{array}$ \\
\hline $\begin{array}{l}\text { NMDA-R NR1/2A } \\
\text { and NR1/2B } \\
\text { subtypes (both } \\
\text { pre- and } \\
\text { postsynapse) }\end{array}$ & $\begin{array}{l}\text { NR1 and NR2A } \\
\text { subunits } \\
\text { (requires } \\
\text { assembled } \\
\text { subunits) }\end{array}$ & $\begin{array}{l}\text { Transmembrane } \\
\text { C-terminal } \\
\text { region }^{a}\end{array}$ & $\begin{array}{l}\text { Coimmunoprecipitation; } \\
\text { FRET fluorescence }\end{array}$ & $\begin{array}{l}\uparrow \text { NMDA current; } \\
\uparrow \text { presynaptic } \\
\text { release }\end{array}$ & $\begin{array}{l}\downarrow \text { NMDA current, } \downarrow \\
\alpha_{2} \delta \text {-1-NMDA-R } \\
\text { binding }\end{array}$ & $\begin{array}{l}\text { Chen et al., 2018; } \\
\text { Luo et al., } \\
\text { 2018; Ma } \\
\text { et al., } 2018\end{array}$ \\
\hline Neurexin- $1 \alpha$ & $\begin{array}{l}\text { Neurexin-1 } \alpha \text { LG } \\
\text { domains } 1 \\
\text { and } 5\end{array}$ & $? ?$ & Coimmunoprecipitation & & Not tested & Tong et al., 2017 \\
\hline $\begin{array}{l}\text { Neurexin- } 1 \alpha \\
\quad \text { ectodomain } \\
\text { (applied to } \mathrm{CHO} \\
\text { cells with } \\
\text { expressed } \mathrm{Ca} \\
\text { channel } \\
\text { subunits) }\end{array}$ & $\begin{array}{l}\text { Neurexin-1 } \alpha \\
\text { ectodomain }\end{array}$ & $? ?$ & $\begin{array}{l}{\left[{ }^{3} \mathrm{H}\right] \text { gabapentin binding }} \\
\text { to CHO cell } \\
\text { membranes }\end{array}$ & $\begin{array}{l}\text { Added neurexin } \\
\text { ectodomain } \\
\text { reduces } \\
\text { gabapentin- } \alpha_{2} \delta- \\
1 \text { binding }\end{array}$ & $\begin{array}{l}\downarrow \text { EPSC and size of } \\
\text { readily releasable } \\
\text { pool in cultured } \\
\text { sympathetic } \\
\text { neurons }\end{array}$ & $\begin{array}{l}\text { Martínez San } \\
\text { Segundo et al., } \\
2020\end{array}$ \\
\hline Neurexin-1 $\alpha$ & $? ?$ & $? ?$ & $\begin{array}{l}\text { Mobility of } \alpha_{2} \delta-1 \text { single } \\
\text { particles reduced by } \\
\text { added neurexin; } \\
\text { reported nonspecific } \\
\text { coimmunoprecipitation }\end{array}$ & & & $\begin{array}{l}\text { Brockhaus et al., } \\
2018\end{array}$ \\
\hline $\begin{array}{l}\text { Thrombospondin- } \\
\text { 1, -2, and -4; } \\
\text { (source: } \\
\text { astrocytes) } \\
\text { neocortex }\end{array}$ & $\begin{array}{l}\text { EGF-like repeats } \\
\quad(\text { central region })\end{array}$ & VWF-A domain & $\begin{array}{l}\text { Coimmunoprecipitation; } \\
\text { change in } \alpha_{2} \delta \text {-1 drug } \\
\text { binding when } \\
\text { thrombospondin } \\
\text { present }\end{array}$ & $\begin{array}{l}\uparrow \text { New synapse } \\
\text { formation }\end{array}$ & $\begin{array}{l}\downarrow \text { New synapses; } \\
\quad \text { thrombospondin } \downarrow \\
\quad \text { drug affinity to } \alpha_{2} \delta-1\end{array}$ & $\begin{array}{l}\text { Eroglu et al., } \\
2009 ; \text { Lana } \\
\text { et al., } 2016\end{array}$ \\
\hline Thrombospondin-4 & EGF-like repeats & $? ?$ & $\begin{array}{l}\text { Coimmunoprecipitation; } \\
\text { solid phase binding; } \\
\text { Biacore instrument }\end{array}$ & $\begin{array}{c}\text { Thrombospondin } \\
\text { enhanced pain } \\
\text { required } \alpha_{2} \delta-1\end{array}$ & $\begin{array}{l}\downarrow \text { Sensitivity to pain } \\
\quad \text { and } \downarrow \text { glutamate } \\
\text { release }\end{array}$ & $\begin{array}{l}\text { Park et al., 2016, } \\
2018\end{array}$ \\
\hline $\begin{array}{l}\text { BK potassium } \\
\text { channel }\end{array}$ & N-terminal region & $\begin{array}{l}\text { C-terminal } \\
\text { region }\end{array}$ & Coimmunoprecipitation & $\begin{array}{c}\text { BK competes with } \\
\alpha_{2} \delta-1 \text { actions at } \\
\text { Ca channels }\end{array}$ & None & $\begin{array}{l}\text { Zhang et al., } \\
2018\end{array}$ \\
\hline $\begin{array}{l}\text { LRP1 (cellular } \\
\text { protein traffic) }\end{array}$ & $\begin{array}{l}\text { Heavy-chain LBD } \\
\text { sequences }\end{array}$ & VWF-A domain & $\begin{array}{l}\text { Coimmunoprecipitation; } \\
\text { in vitro protein pull- } \\
\text { down }\end{array}$ & $\begin{array}{l}\text { Modulates } \alpha_{2} \delta \text {-1 } \\
\text { traffic; increases } \\
\alpha_{2} \delta-1 \text { at cell } \\
\text { membrane }\end{array}$ & $\begin{array}{l}\text { LRP1 expression } \downarrow \\
\text { drug binding } B_{\max } \\
\text { to } \alpha_{2} \delta-1\end{array}$ & $\begin{array}{l}\text { Kadurin et al., } \\
2017\end{array}$ \\
\hline
\end{tabular}

EGF, epidural growth factor; GBP, gabapentin; LBD, ligand binding domains; LG, laminin-like globular; NMDA-R, NMDA receptor; PGB, pregabalin; VWF-A domain, von Willebrand factor type-A homology domain.

${ }^{a} \alpha_{2} \delta-2$ and $\alpha_{2} \delta-3$ antibodies did not immunoprecipitate NMDA receptor subunits.

cell adhesion role, $\alpha_{2} \delta$-1 in striate muscle cells promotes adhesion to collagen (Garcia et al., 2008) and increases cell motility.

Recent studies show that $\alpha_{2} \delta$-1 alters the function of proteins other than voltage-gated calcium channels. In particular, gabapentinoids modify certain $N$-methyl-D-aspartate (NMDA)-sensitive glutamate receptors (NMDA receptors), modify some actions of neurexin- $1 \alpha$, and limit some actions of thrombospondin. These effects are unrelated to calcium channels and could contribute to the pharmacological actions of gabapentinoid drugs, but this idea remains controversial and is the focus of this review.

\section{Gabapentinoid Drugs Reduce Neurotransmitter Release}

Previous studies showed that gabapentinoid drugs reduce the release of excitatory neurotransmitters from neuronal tissues by acting at the $\alpha_{2} \delta$-1 binding site [reviewed in Dooley et al. (2007)]. The prevailing thought has been that these drugs act therapeutically to reduce excitability in spinal cord sensory circuits and in neocortex by subtly reducing excitatory neurotransmitter release at many synapses at once, and glutamate synapses in many regions have abundant $\alpha_{2} \delta-1$ protein (Taylor and Garrido, 2008).

The amount of $\alpha_{2} \delta-1$ protein at synapses is remarkably upregulated after neuronal injuries, both in the spinal cord dorsal horn (Luo et al., 2001, 2002; Li et al., 2004, 2006; Bauer et al., 2009; Boroujerdi et al., 2011) and in neocortex (Andresen et al., 2014; Prince et al., 2016; Luo et al., 2018). Interestingly, this upregulation only alters $\alpha_{2} \delta-1$ and not $\alpha_{2} \delta$-2, and the upregulated $\alpha_{2} \delta-1$ is of a different posttranslational splice variant and different glycosylation pattern than endogenous $\alpha_{2} \delta$-1 in the spinal cord (Luo et al., 2001) and dorsal root ganglia (Lana et al., 2014). 
Electron microscopy has shown localization of $\alpha_{2} \delta$-1 protein both presynaptically and postsynaptically in rodent dorsal spinal cord (Bauer et al., 2009), with about twice as much immunoreactivity presynaptically as postsynaptically. Also, after neuropathic injury, $\alpha_{2} \delta$-1 increases only at presynaptic sites (Fig. 3).

Several studies show that gabapentin and pregabalin reduce the spontaneous rate of release of vesicles from glutamate synapses, measured by miniature excitatory synaptic currents (mEPSCs), which reflect the release of individual synaptic vesicles. Unlike synaptic responses triggered by action potentials, mEPSCs are insensitive to the sodium channel blocker tetrodotoxin, and the vesicles released spontaneously are regulated differently from the vesicle pool released by action potentials [reviewed in Ramirez and Kavalali (2011)]. For example, spontaneous release occurs from a separate pool of vesicles (Sara et al., 2005) and is regulated by different synaptic proteins (Groffen et al., 2010) than evoked release. A recent study (Ferron et al., 2018) shows that the presence of mature $\alpha_{2} \delta$-1 in cultured neurons promotes both synchronous and asynchronous neurotransmitter release.

Such mEPSCs recorded in dorsal spinal cord (or trigeminal nucleus) neurons typically have rates in the range of $0.2-1.0$ $\mathrm{Hz}$, and the rate is augmented in response to experimental peripheral nerve damage ( $\mathrm{Li}$ et al., 2014a,b; Zhou and Luo, 2015; Alles et al., 2017; Chen et al., 2018), chemotherapyinduced allodynia (Chen et al., 2019), and allodynia from tolerance to repeated morphine treatment (Deng et al., 2019) or from artificial excess expression of $\alpha_{2} \delta$ - 1 genes (Zhou and Luo, 2014). In each of these studies, the drugs gabapentin or pregabalin normalize pathologically elevated rates of mEPSCs in rat or mouse neuronal tissue with synapses in spinal cord dorsal horn (Patel et al., 2000; Li et al., 2014b; Matsuzawa et al., 2014; Zhou and Luo, 2014, 2015; Park et al., 2016; Alles et al., 2017; Chen et al., 2018, 2019; Deng et al., 2019). Gabapentinoids reduced the rate of mEPSCs between glutamatergic neurons in rat entorhinal cortex (Cunningham et al., 2004), in neocortex neurons after cortical freeze lesions (Andresen et al., 2014; Lau et al., 2017), between neocortex and striatal neurons (Zhou et al., 2018), at glutamate neurons in hypothalamus of spontaneously hypertensive rats (Ma et al., 2018), at the mouse calyx of Held (Di Guilmi et al., 2011), and in corticostriatal synapses after prolonged prior stimulation of striatum (Nagai et al., 2019). Therefore, the most widely replicated effects of gabapentin and pregabalin at the cellular level are decreases in the rate of mEPSCs at excitatory synapses, particularly at synapses with pathologically enhanced activity. Interestingly, gabapentin had little effect on the rate of mEPSCs recorded in inhibitory neurons in dorsal spinal cord (Zhou and Luo, 2015; Alles et al., 2017).

Despite agreement that gabapentinoid drugs reduce the rate of spontaneous mEPSCs and also subtly reduce bulk neurotransmitter release from whole tissues, it is not clear whether these effects result from decreased current through presynaptic calcium channel $\alpha_{1}$ subunits. In fact, one set of studies showed that overexpression of $\alpha_{2} \delta$-1 in cultured cortex neurons increases neurotransmitter release and synaptic localization of calcium channels but decreases presynaptic calcium influx (Hoppa et al., 2012, 2014).

\section{Additional Binding Partners of $\alpha_{2} \delta$-1}

Although $\alpha_{2} \delta$-1 was originally identified in association with voltage-gated calcium channels, it has subsequently been found to associate with proteins other than calcium channels based on several methods (see Fig. 2 and Table 1). There is also evidence from fluorescent microscopy of living cells (Table 2), including the extracellular matrix proteins, collagen, and thrombospondin. In addition, gabapentin binding to $\alpha_{2} \delta-1$ prevents both thrombospondin and NMDA receptors from augmenting the release of glutamate at synapses and also prevents thrombospondin from promoting the formation of new glutamate synapses (see sections below). The $\alpha_{2} \delta-1$ protein has several unusual properties that may contribute to its selectivity in interacting with other proteins. It is highly glycosylated (decorated with polysaccharides) and is found concentrated in cholesterol-rich and detergent-resistant membrane microdomains called lipid rafts (Davies et al., 2006; Dolphin, 2013, 2016). In addition, mature $\alpha_{2} \delta$-1 seems to exist in some situations bound to membranes by a glycosylphosphatidylinositol anchor (GPI anchor), attached during posttranslational protein processing (Davies et al., 2010). The GPI anchor is needed for $\alpha_{2} \delta$-1 interaction with calcium channel $\alpha_{1}$ (Davies et al., 2010) but not for interactions with thrombospondin (Risher et al., 2018) or NMDA receptors (Chen et al., 2018). The GPI anchor adheres the protein to only the outer leaflet of the plasma membrane (Alvarez-Laviada et al., 2014) and favors localization in cholesterol-rich membrane areas. The putative relationships of $\alpha_{2} \delta-1$ with several of these known protein binding partners are shown in Fig. 3. Three-dimensional structures of partner proteins have been determined, including the voltage-gated calcium channel (Wu et al., 2016), $\alpha$-neurexin (Miller et al., 2011), thrombospondin (Carlson et al., 2008), heteromeric NMDA receptors (Karakas and Furukawa, 2014), and BK calcium-dependent potassium channels (Yuan et al., 2010). The evidence for gabapentinoid drugs acting via these various proteins is discussed below, beginning with NMDA receptors, for which there is the most evidence.

\section{NMDA Receptor Interaction with $\alpha_{\mathbf{2}} \delta$-1}

Early in the investigation of the mechanism of action of gabapentin, it was suggested that NMDA receptors in brain and spinal cord were mediators of its pharmacology (Oles et al., 1990; Singh et al., 1996; Jun and Yaksh, 1998; Yoon and Yaksh, 1999), but this suggestion was generally overlooked. Results with gabapentinoid drugs in models of NMDA receptor function are summarized in Table 3 . The early studies showed that the analgesic, anticonvulsant, and anxiolytic actions of gabapentin in rodent models were prevented by prior intracerebroventricular injection with the NMDA receptor glycine site agonist D-serine but not its inactive stereoisomer L-serine (D-serine injections alone did not alter behavioral responses). These findings with animal models resembled those with HA-966 (Singh et al., 1990), an experimental drug with partial agonist actions at the NMDA receptor glycine site. In addition, an unpublished doctoral thesis showed that isolated rat striatal neurons have electrical responses to NMDA plus glycine that were reduced by gabapentin, and gabapentin alone behaved like a glycine site partial agonist (Sprosen, 1991). However, these authors noted that gabapentin did not displace radiolabeled glycine binding 

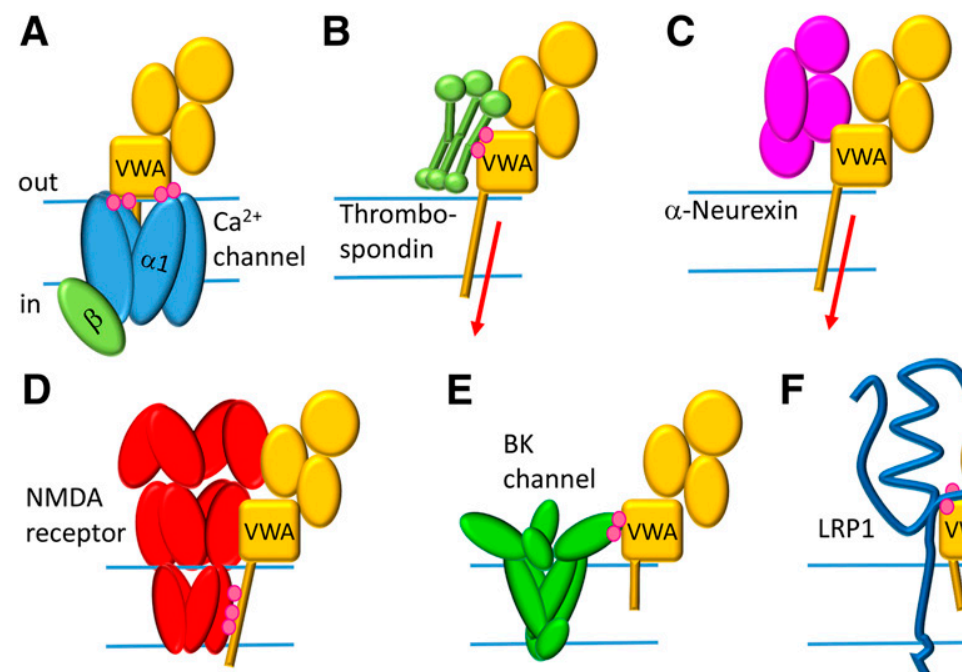

E

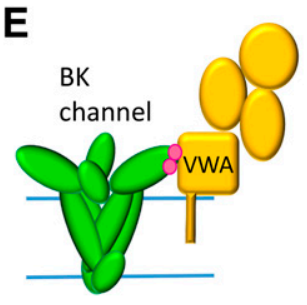

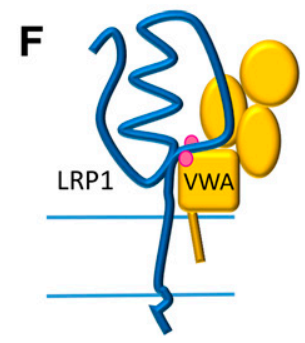

Fig. 2. Proposed direct molecular interactions of $\alpha_{2} \delta-1$ protein (yellow) with other neuronal proteins. The outside (out) and inside (in) of the cell membrane are indicated and are the same in (B-F). Evidence is based mostly on coimmunoprecipitation of solubilized proteins ex vivo (see text and Table 1 for more details). In each case, presumed sites of protein-protein interaction are shown with pink ovals. (A) The extracellular loops of the voltage-gated calcium channel $\alpha_{1}$ subunit (blue) bind to the VWA domain of $\alpha_{2} \delta-1$ (Gurnett et al., 1997; Wu et al., 2016). Note that this appears to require a GPI-linked $\alpha_{2} \delta-1$ protein (Davies et al., 2010). (B) The EGF-like (epidermal growth factor) repeats of the thrombospondin trimer (thrombospondin-1 and -2 , light green) or pentamer (thrombospondin-4, data not shown) bind to VWA to signal across the membrane via the $\alpha_{2} \delta$ - 1 transmembrane domain (yellow) to intracellular proteins, including Rac1 (red arrow), requiring a transmembrane variant of $\alpha_{2} \delta$-1 (Risher et al., 2018). (C) An unknown extracellular part of $\alpha_{2} \delta$-1 interacts with the soluble ectodomain regions LG-1 and LG-5 (laminin-like globular domains) of neurexin- $1 \alpha$ (Tong et al., 2017). This interaction reduces radioligand binding of gabapentin to $\alpha_{2} \delta-1$ (Martínez San Segundo et al., 2020), and gabapentin applied to this complex signals to the presynaptic cytosol to reduce the effective size of the readily releasable pool of vesicles (Martínez San Segundo et al., 2020). (D) The $\alpha_{2} \delta-1$ transmembrane domain interacts with an unknown sequence on NMDA receptor NR1/NR2A and NR1/NR2B proteins (red) (Chen et al., 2018) to alter NMDA receptor function. (E) BK-type calcium-dependent potassium channels (bright green) associate with $\alpha_{2} \delta-1$ in a mutually exclusive manner with calcium channel $\alpha_{1}$ (Zhang et al., 2018), but effects of gabapentinoid drugs on BK channels (if any) are not known. (F) LRP1 (blue) binds to the $\alpha_{2} \delta$-1 VWA domain via two extracellular ligand binding domains (Kadurin et al., 2017). at NMDA receptors, and D-serine did not interact with gabapentin radioligand binding at $\alpha_{2} \delta-1$, so they concluded that the gabapentin-NMDA receptor interaction, if real, must be indirect (Singh et al., 1996). Pregabalin also was later shown not to interact with binding sites on NMDA receptors (Li et al., 2011). Once it was shown that drug binding to $\alpha_{2} \delta-1$ was required for the pharmacology of gabapentin and pregabalin, the early findings regarding gabapentin and NMDA receptor responses were mostly forgotten. However, it is now clear that, in addition to calcium channels, $\alpha_{2} \delta-1$ interacts with NMDA receptors and several other proteins.

\section{NMDA Receptor Proteins Bind Directly to $\alpha_{2} \delta-1$}

NMDA receptors consist of a tetramer of both NR1 and NR2 subunits (NR1/NR2A and NR1/NR2B are most common in brain, with occasional NR1/NR3), and they are located both presynaptically and postsynaptically in spinal cord and brain (Traynelis et al., 2010). Chen and coworkers from the H.L. Pan laboratory (Chen et al., 2018) showed with coimmunoprecipitation that $\alpha_{2} \delta$ - 1 interacts with the NMDA receptors of GluN1/ $2 \mathrm{~A}$ and GluN1/2B types by binding that requires a specific sequence on the GluN1 subunit. This physical interaction between proteins also requires complete multimeric NMDA receptor proteins because single subunits (GluN1, GluN2A, or GluN2B) did not interact with $\alpha_{2} \delta$-1. The interaction occurs between the membrane-spanning C-terminal region of $\alpha_{2} \delta$-1 and an unidentified region of NMDA receptor heteromers that includes the NR1 subunit. These interactions between $\alpha_{2} \delta$-1 and NMDA receptors do not require the widely studied von Willebrand domain of the $\alpha_{2} \delta-1$ protein, in contrast to the interaction between $\alpha_{2} \delta$-1 and thrombospondin (Eroglu et al., 2009) or between $\alpha_{2} \delta$-1 and calcium channel $\alpha_{1}$ subunits (Canti et al., 2005). Furthermore, studying fluorescent resonance energy transfer (FRET) between tagged $\alpha_{2} \delta$-1 proteins and tagged NMDA receptors in model cells, Chen et al. (2008) showed that FRET (which is absent unless the two proteins are physically adjacent) is absent in the presence of gabapentin (Chen et al., 2018). Additional data suggest that gabapentin decreases the physical interaction between $\alpha_{2} \delta$-1 and NMDA receptors in this system and also disrupts traffic of both $\alpha_{2} \delta$-1 and NMDA receptors from the cytosol to the cell membrane. In addition, experimental coexpression of $\alpha_{2} \delta$-1 with GluN1/2A alters NMDA receptor properties such that much more inward current occurs at membrane potentials between -80 and $-20 \mathrm{mV}$; that is, $\alpha_{2} \delta-1$ reduces magnesium block of the NMDA receptor channel, which ordinarily prevents current from flowing at resting potentials. Magnesium block ordinarily prevents NMDA receptors from functioning at resting membrane potentials and causes NMDA receptors to function as coincidence detectors, only active with simultaneous glutamate activation and cell membrane depolarization (Traynelis et al., 2010). The reduced magnesium block was not seen when $\alpha_{2} \delta-1$ was coexpressed with GluN1/2B receptors but was only seen with GluN1/2A receptors (Chen et al., 2018). Importantly, the effect of $\alpha_{2} \delta$-1 on magnesium block was completely absent in the presence of gabapentin. These results suggest that association of NMDA GluN1/2A receptors with $\alpha_{2} \delta$ - 1 would cause more than the normal amount of glutamategated current near resting membrane voltages, but this augmentation of NMDA receptor responses would be reduced by gabapentinoid drugs. 
TABLE 2

Evidence for protein interactions with $\alpha_{2} \delta$-1 in whole cells or tissues

\begin{tabular}{|c|c|c|c|c|c|}
\hline Target Protein & $\alpha_{2} \delta-1$ Region & Experimental Method & Effect of $\alpha_{2} \delta-1$ on Target & GBP or PGB Effect & Reference \\
\hline Collagen I & $? ?$ & $\begin{array}{l}\text { Fluorescent antibodies to } \\
\alpha_{2} \delta-1, \text { siRNA to } \alpha_{2} \delta-1 \\
\text { and measured cell } \\
\text { motility }\end{array}$ & $\begin{array}{l}\text { Increased adhesion and } \\
\text { motility of muscle } \\
\text { cells on collagen } \\
\text { substrate }\end{array}$ & Not tested & Garcia et al., 2008 \\
\hline $\begin{array}{l}\text { NMDA receptor NR1 } \\
\text { subunit and } \\
\text { thrombospondin }\end{array}$ & $\begin{array}{c}\text { Membrane-spanning } \\
\text { C-terminal region }\end{array}$ & $\begin{array}{l}\text { Thrombospondin effect } \\
\text { on nascent dendritic } \\
\text { spines (via } \alpha_{2} \delta-1 \text { ) }\end{array}$ & $\begin{array}{l}\text { Increased size and } \\
\text { stability of dendritic } \\
\text { spines }\end{array}$ & $\begin{array}{l}\text { Disrupts stability of } \\
\text { new spines }\end{array}$ & Risher et al., 2018 \\
\hline $\begin{array}{l}\text { NMDA receptors } \\
\text { containing NR1 } \\
\text { subunit }\end{array}$ & $\begin{array}{c}\text { Membrane-spanning } \\
\text { C-terminal region }\end{array}$ & $\begin{array}{l}\text { NMDA receptors and } \\
\alpha_{2} \delta-1 \text { coexpressed in } \\
\text { model cells }\end{array}$ & $\begin{array}{l}\text { Increased NMDA } \\
\text { current at negative } \\
\text { voltages }\end{array}$ & $\begin{array}{l}\text { Blocks NMDA } \\
\text { current only at } \\
\text { negative voltages }\end{array}$ & Chen et al., 2018 \\
\hline Thrombospondin & $\begin{array}{l}\text { VWA domain (requires } \\
\text { membrane-spanning } \\
\text { protein) }\end{array}$ & $\begin{array}{l}\text { New synapse formation } \\
\text { in vitro and in vivo }\end{array}$ & $\begin{array}{l}\text { Increased number of } \\
\text { synapses and } \\
\text { synaptic strength }\end{array}$ & $\begin{array}{l}\text { Reduces new } \\
\text { synapse formation }\end{array}$ & Risher et al., 2018 \\
\hline $\begin{array}{l}\mathrm{K}_{\mathrm{V}} 3.1 \text { and } \mathrm{K}_{\mathrm{V}} 1 \\
\text { potassium } \\
\text { channels }\end{array}$ & $? ?$ & $\begin{array}{l}\text { Rapid membrane voltage } \\
\text { fluorescent sensor }\end{array}$ & $\begin{array}{l}\uparrow \text { Potassium channel } \\
\text { function at release } \\
\text { sites; } \downarrow \text { presynaptic } \\
\text { spike duration }\end{array}$ & Not tested & Hoppa et al., 2014 \\
\hline $\begin{array}{l}\alpha \text {-Neurexin } \\
\quad \text { (presynaptic cell } \\
\text { adhesion molecule) }\end{array}$ & $? ?$ & $\begin{array}{l}\text { Presynaptic calcium } \\
\text { influx (fluorescent dye) }\end{array}$ & $\begin{array}{l}\alpha_{2} \delta-1 \text { allows neurexin to } \\
\uparrow \text { calcium current; } \\
\text { neurexin decreases } \\
\alpha_{2} \delta-1 \text { mobility }\end{array}$ & Not tested & $\begin{array}{l}\text { Brockhaus et al., } \\
2018\end{array}$ \\
\hline $\begin{array}{l}\text { Synaptotagmin } \\
\text { (presynaptic } \\
\text { release protein) }\end{array}$ & $\begin{array}{l}\text { Secondary to effect at } \\
\text { Cav } \alpha 1 \text { subunit? }\end{array}$ & $\begin{array}{l}\text { Synapse fluorescence to } \\
\text { antibodies }\end{array}$ & $\begin{array}{l}\uparrow \text { Synaptotagmin } \\
\text { amount at active zone }\end{array}$ & Unknown & $\begin{array}{l}\text { Schneider et al., } \\
2015\end{array}$ \\
\hline $\begin{array}{l}\text { Bassoon (presynaptic } \\
\text { scaffold protein) }\end{array}$ & $\begin{array}{l}\text { Secondary to effect at } \\
\text { Cav } \alpha 1 \text { subunit? }\end{array}$ & $\begin{array}{l}\text { Synapse fluorescence to } \\
\text { antibodies }\end{array}$ & $\begin{array}{l}\uparrow \text { Bassoon amount at } \\
\text { active zone; } \uparrow \text { size of } \\
\text { bassoon puncta }\end{array}$ & Unknown & $\begin{array}{l}\text { Schneider et al., } \\
2015\end{array}$ \\
\hline $\begin{array}{l}\text { RIM (presynaptic } \\
\text { release protein) }\end{array}$ & $\begin{array}{l}\text { Secondary to effect at } \\
\text { Cav } \alpha 1 \text { subunit? }\end{array}$ & $\begin{array}{l}\text { Synapse fluorescence to } \\
\text { antibodies }\end{array}$ & $\begin{array}{l}\uparrow \text { RIM amount at active } \\
\text { zone; } \uparrow \text { size of RIM } \\
\text { puncta }\end{array}$ & Unknown & $\begin{array}{l}\text { Schneider et al., } \\
2015\end{array}$ \\
\hline $\begin{array}{l}\text { RAP (receptor } \\
\text { associated protein) }\end{array}$ & $\begin{array}{l}\text { Secondary to LRP1 } \\
\text { action? }\end{array}$ & & $\begin{array}{l}\text { RAP increases cell surface } \\
\text { expression of } \alpha_{2} \delta-1 \text { (also } \\
\text { requires LRP1) }\end{array}$ & Unknown & Kadurin et al., 2017 \\
\hline
\end{tabular}

GBP, gabapentin; PGB, pregabalin; RIM, Rab3-interacting molecules; VWF-A domain, von Willebrand factor type-A homology domain.

For cases in which it was tested, the ability of gabapentin and pregabalin to reduce spontaneous vesicle release in chronic-pain models was absent if NMDA receptors were blocked in spinal cord dorsal horn neurons (Chen et al., 2018, 2019; Deng et al., 2019). Similarly, pregabalin reduced spontaneous vesicle release (measured by release of fluorescent dye from synaptic vesicles) from synapses in cultured hippocampal neurons (Micheva et al., 2006), but not with NMDA receptors blocked. Since $\alpha_{2} \delta$-1 is expressed mostly presynaptically, it is likely that presynaptic membranes

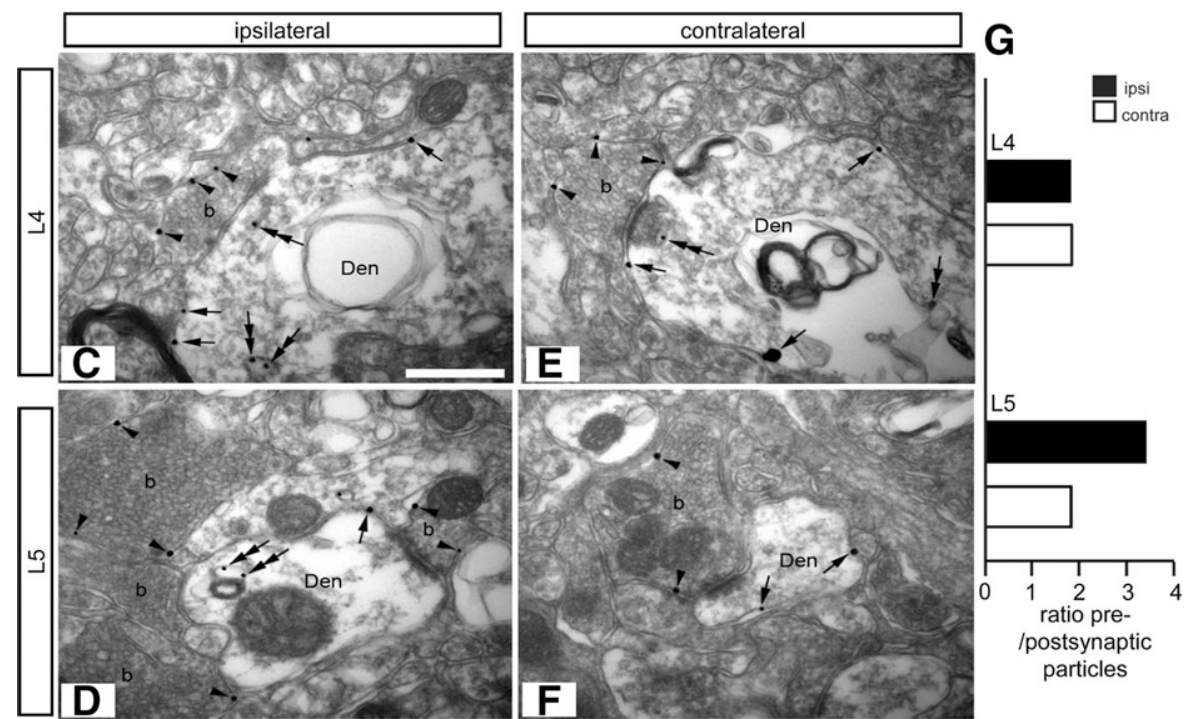

Fig. 3. Representative electron micrographs ipsilateral $(\mathrm{C}$ and $\mathrm{D})$ and contralateral $(\mathrm{E}$ and F) to spinal nerve damage. Dots show immunogold labeling of $\alpha_{2} \delta-1$ in the dorsal horn (lamina I-III) of L4 and L5 spinal cord sections 14 days after sensory nerve ligation that causes allodynia. Scale bar, $0.5 \mu \mathrm{m}$. (Arrowheads show presynaptic sites at the plasma membrane of excitatory axon terminal boutons ("b"), characterized by round synaptic vesicles and postsynaptic density). Arrows show postsynaptic sites at the extrasynaptic plasma membrane of dendritic shafts (Den); double arrows show intracellular dendritic sites. (G) Ratio of presynaptic to postsynaptic numbers of particles on the sides ipsilateral (filled bars) and contralateral (open bars) to injury. Figure reproduced from Bauer et al. (2009) with permission (copyright 2009, Society for Neuroscience). 
TABLE 3

Effect of gabapentin and pregabalin on NMDA receptor-dependent responses

\begin{tabular}{|c|c|c|c|c|c|c|}
\hline Preparation & Synapse & $\begin{array}{c}\alpha_{2} \delta-1 \\
\text { Upregulation? }\end{array}$ & $\begin{array}{l}\text { Holding } \\
\text { Potential }\end{array}$ & Coagonists & Drug Effect & Reference \\
\hline $\begin{array}{l}\text { Rat cultured striatal } \\
\text { neurons }\end{array}$ & $\begin{array}{c}\text { None (NMDA } \\
\text { application) }\end{array}$ & No & $-60 \mathrm{mV}$ & $\begin{array}{l}\text { Glycine } \\
\text { (various) }\end{array}$ & $\begin{array}{l}\text { GBP }(10-200 \mu \mathrm{M}) \text { similar to } \\
\text { glycine site partial agonist; } \\
\text { occluded by D-serine }\end{array}$ & Sprosen, 1991 \\
\hline $\begin{array}{l}\text { Rat spinal dorsal } \\
\text { horn neurons }\end{array}$ & $\begin{array}{l}\text { Glutamate sensory } \\
\text { afferents; NMDA } \\
\text { application }\end{array}$ & No & $+50 \mathrm{mV}$ & None & $\begin{array}{l}\text { GBP }(100 \mu \mathrm{M}) \downarrow \text { NMDA EPSCs } \\
\quad(\text { fraction of cells); GBP }(100 \mu \mathrm{M}) \\
\uparrow \text { response to NMDA application }\end{array}$ & $\begin{array}{l}\text { Moore et al., } \\
2002\end{array}$ \\
\hline $\begin{array}{l}\text { Rat dorsal spinal } \\
\text { GABA neurons }\end{array}$ & $\begin{array}{l}\text { None (NMDA } \\
\text { application) }\end{array}$ & $\begin{array}{c}\text { Not } \\
\text { measured }\end{array}$ & $-60 \mathrm{mV}$ & $\begin{array}{l}\text { Glycine } \\
\text { (various) }\end{array}$ & $\begin{array}{l}\text { GBP }(100 \mu \mathrm{M}) \uparrow \text { NMDA response } \\
\text { with PKC activation; occluded } \\
\text { by glycine }\end{array}$ & $\begin{array}{l}\text { Gu and Huang, } \\
2001,2002\end{array}$ \\
\hline Rat hippocampus & $\begin{array}{l}\text { Glutamate afferents } \\
\text { to CA1 }\end{array}$ & No & $\begin{array}{l}\text { Extracellular } \\
\text { record }\end{array}$ & None & $\begin{array}{l}\text { GBP }(50-200 \mu \mathrm{M}) \downarrow \text { field EPSP by } \\
25 \% \text { (prevented by NMDA } \\
\text { antagonist) }\end{array}$ & $\begin{array}{l}\text { Suarez et al., } \\
2005\end{array}$ \\
\hline $\begin{array}{l}\text { Cultured rat } \\
\text { hippocampal } \\
\text { neurons }\end{array}$ & $\begin{array}{l}\text { Recurrent } \\
\text { glutamate } \\
\text { synapses }\end{array}$ & No & $\begin{array}{l}\text { Fluorescent } \\
\text { signal }\end{array}$ & None & $\begin{array}{l}\text { PGB }(100 \mu \mathrm{M}) \downarrow \text { vesicle release } \\
\text { (prevented by NMDA } \\
\text { antagonist) }\end{array}$ & $\begin{array}{l}\text { Micheva et al., } \\
2006\end{array}$ \\
\hline Mouse hippocampus & $\begin{array}{l}\text { CA1 NMDA } \\
\text { application }\end{array}$ & Yes & $?$ & None & $\begin{array}{l}\text { GBP }(30-100 \mu \mathrm{M}) \downarrow \text { NMDA } \\
\text { response } 40 \% \text { only after } \\
\text { ischemia }\end{array}$ & Luo et al., 2018 \\
\hline Rat hippocampus & $\begin{array}{l}\text { Glutamate afferents } \\
\text { to CA1 (after } \\
\text { perinatal ethanol) }\end{array}$ & Yes? & $-30 \mathrm{mV}$ & None & $\begin{array}{l}\text { GBP }(30 \mu \mathrm{M}) \downarrow \text { GluN2A- synaptic } \\
\text { currents only after perinatal } \\
\text { ethanol exposure }\end{array}$ & $\begin{array}{l}\text { Swartzwelder } \\
\text { et al., } 2017\end{array}$ \\
\hline Rat striatum & $\begin{array}{l}\text { Medium spiny } \\
\text { GABA neurons; } \\
\text { cortex afferents }\end{array}$ & No & $-80 \mathrm{mV}$ & None & $\begin{array}{l}\text { GBP }(100 \mu \mathrm{M} ; 30 \mathrm{~min}) \text { blocked } \\
\text { NMDA-dependent LTP }(\theta \text {-burst } \\
\text { stimulation) }\end{array}$ & Zhou et al., 2018 \\
\hline $\begin{array}{l}\text { Rat PVN } \\
\text { hypothalamus } \\
\text { (SHR } \\
\text { hypertensive) }\end{array}$ & $\begin{array}{l}\text { NMDA application; } \\
\text { glutamate } \\
\text { afferents }\end{array}$ & Yes & $\begin{array}{l}-60 \mathrm{mV} \\
+30 \mathrm{mV}\end{array}$ & None & $\begin{array}{l}\text { GBP }(100 \mu \mathrm{M}) \downarrow \text { rate of } \\
\text { glutamatergic mEPSCs; } \downarrow \\
\text { NMDA puff response } 40 \%\end{array}$ & Ma et al., 2018 \\
\hline Xenopus oocyte & $\begin{array}{l}\text { NR1/NR2A human } \\
\text { NMDA receptor }\end{array}$ & No & $-70 \mathrm{mV}$ & $\begin{array}{l}\text { L-glutamate }+ \\
10 \mu \mathrm{M} \text { glycine }\end{array}$ & $\begin{array}{l}\text { GBP }(10-300 \mu \mathrm{M}) \downarrow \text { glutamate } \\
\text { response up to } 50 \% \text {; reversed by } \\
\text { glycine }\end{array}$ & $\begin{array}{l}\text { Hara and Sata, } \\
2007\end{array}$ \\
\hline
\end{tabular}

GBP, gabapentin; PGB, pregabalin; PKC, protein kinase C; PVN, paraventricular nucleus; SHR, spontaneously hypertensive rats.

are an important anatomic site of $\alpha_{2} \delta$ - 1 interactions with NMDA receptors, as suggested experimentally (Chen et al., 2018, 2019; Zhou et al., 2018; Deng et al., 2019). However, it will require additional studies to conclusively show that presynaptic NMDA receptors are uniquely sensitive to gabapentinoids. In summary, it is likely that gabapentin and pregabalin reduce spontaneous (miniature) synaptic release in several regions of brain, a manner that requires $\alpha_{2} \delta$-1-linked presynaptic NMDA receptors.

Although considerable evidence links gabapentinoid drugs to some NMDA receptors, the anatomic distribution of immunostained NMDA receptors in brain (Petralia et al., 1994) is quite different from that for immunostained $\alpha_{2} \delta-1$ (Taylor and Garrido, 2008). For example, NMDA receptor immunostaining is most dense in cell body layers of hippocampus (where $\alpha_{2} \delta$-1 immunostaining is sparse), with denser $\alpha_{2} \delta$-1 immunostaining in dendritic layers. Furthermore, a survey of gabapentinoid actions on NMDA receptor-dependent processes (Table 3) shows both inhibitory effects and negligible effects in different preparations. Therefore, it is clear that $\alpha_{2} \delta-1$ proteins and gabapentinoid drugs interact only with a subset of NMDA receptors.

\section{Analgesia Produced by Gabapentinoids Compared with Known NMDA Antagonists}

NMDA antagonists acting at all NMDA receptors have pharmacological profiles very different from the gabapentinoids and are far from ideal analgesic, antiseizure, or anxiolytic drugs. To date, no broad-spectrum NMDA antagonist drug has proven useful for treating epilepsy or chronic pain in humans, likely because broad-spectrum NMDA antagonists have undesirable properties consisting of feeling dissociated from present time and surroundings (dissociative effects) (van Schalkwyk et al., 2018), memory disruption, confusion, agitation, nausea, and sometimes psychosis, particularly at high dosages. This contrasts with gabapentin and pregabalin, which do not notably cause dissociative effects, disrupt memory, or cause agitation or psychosis in clinical use. Although ketamine (the most widely studied NMDA antagonist for treating pain) is used primarily for perisurgical pain (Kreutzwiser and Tawfic, 2019) and increasingly for treatment-resistant depression (Murrough et al., 2013; van Schalkwyk et al., 2018), it is not used for chronic neuropathic pain (Gilron, 2007), and it has strong psychotomimetic properties (Sos et al., 2013).

In contrast to recent findings that pregabalin reduces NMDA receptor responses in some regions (e.g., Zhou et al., 2018), studies show that gabapentin and pregabalin have variable effects on long-term potentiation (LTP) of glutamate synapses (Table 3), with most studies showing either no effect or a very modest action of these drugs on the formation of LTP, which is widely accepted to require activation of postsynaptic NMDA receptors.

Despite these findings, the H.L. Pan laboratory recently showed that, in vitro, gabapentin completely prevents NMDA receptor-dependent LTP of neocortical afferents to the dorsal striatum (Zhou et al., 2018) by an action on $\alpha_{2} \delta-1$ that modulates both presynaptic and postsynaptic NMDA 
receptors. It was previously shown that corticostriatal LTP requires presynaptic NMDA receptors (Park et al., 2014), and it has become clear that presynaptic NMDA receptors have different properties from the more widely studied postsynaptic NMDA receptors of neocortical and hippocampal neurons (Banerjee et al., 2016; Dore et al., 2017; Bouvier et al., 2018). Other findings suggest that gabapentin may reduce presynaptic NMDA receptor activity in area CA1 of rat hippocampal slices (Suarez et al., 2005) and in entorhinal cortex slices, where gabapentin reduced the occurrence of spontaneous miniature synaptic events (Cunningham et al., 2004). Furthermore, both gabapentin and pregabalin inhibit cortical spreading depression in vitro (Cain et al., 2017), which might result from inhibiting presynaptic NMDA receptors (Zhou et al., 2013). In summary, there is solid evidence of an interaction between $\alpha_{2} \delta$-1 drugs and NMDA receptor function, but it appears that inhibition is restricted to only a few brain locations and/or at a molecular subset of NMDA receptors (Chen et al., 2018; Luo et al., 2018; Ma et al., 2018; Zhou et al., 2018).

Some recent authors (Chen et al., 2018) have proposed that an $\alpha_{2} \delta$-1-NMDA receptor interaction is required for analgesic actions of gabapentin and pregabalin in animal models and in clinical use. However, this has only been demonstrated in the sensory nerve ligation model of neuropathic pain with spinal reflex-like tactile responding in mice. Analgesia with gabapentin or pregabalin for pain-related responses in animals that are not reflex-like and that require the forebrain have not been studied to see if they rely upon $\alpha_{2} \delta$-1 interactions with NMDA receptors. See, for example, Bannister et al., (2017).

Furthermore, it is clear that NMDA receptors are not required for all of the actions of gabapentin or pregabalin. For example, gabapentin rapidly reduces the frequency of spontaneous miniature excitatory synaptic potentials in dorsal horn neurons of sensory nerve ligated mice (an apparently presynaptic action), even in the presence of an NMDA antagonist (Zhou and Luo, 2015). Nevertheless, it is quite interesting that gabapentin alters NMDA receptor function in animal models of acute focal ischemia (Luo et al., 2018) and at corticostriate glutamate afferent inputs to the striatum (Zhou et al., 2018), including LTP of the corticostriate pathway.

In summary, NMDA receptors newly incorporated into neuronal membranes after ischemia (Luo et al., 2018), neuropathic pain stimulation (Chen et al., 2018, 2019), or spreading depression (Cain et al., 2017) may be particularly sensitive to gabapentin and pregabalin, as are certain native NMDA receptors located in brain regions such as the striatum (Zhou et al., 2018).

\section{$\alpha_{2} \delta$-1 Proteins Interact with Only Certain NMDA Receptors}

Presynaptic NMDA receptors (Banerjee et al., 2016; Abrahamsson et al., 2017; Bouvier et al., 2018) have been studied between nearby pyramidal neurons of neocortex, on corticoamygdalar glutamatergic endings, and in long-term depression in the hippocampus that is timing-dependent. These receptors are important for use-dependent facilitation of glutamate release (Woodhall et al., 2001; Li et al., 2008, 2009), and presynaptic NMDA receptors have specific protein subunits that differ from those of the more widely studied postsynaptic NMDA receptors. For example, mature mice have predominantly GluN1/GluN2B subunits at presynaptic NMDA receptors between neocortical and hippocampal neurons (Woodhall et al., 2001; Larsen et al., 2011), whereas postsynaptic GluN1/GluN2A and GluN1/GluN2B receptors both contribute to LTP in hippocampus (Liu et al., 2004; Berberich et al., 2005). Glutamate receptors consisting of GluN1/GluN2B subunits are also required for long-term depression in hippocampus (Liu et al., 2004). Although details are not yet very clear, it is likely that gabapentinoids and NMDA antagonists differ functionally by acting at distinct subpopulations of NMDA receptors. Previous studies suggested that some cellular actions of gabapentin and pregabalin require activation of protein kinases ( $\mathrm{Gu}$ and Huang, 2001; Maneuf and McKnight, 2001; Fehrenbacher et al., 2003), and it is clear that enhanced NMDA receptor function from phosphorylation contributes to neuropathic and chronic pain (Salter and Kalia, 2004; Salter and Pitcher, 2012). It has not yet been studied whether alternative splicing (Sengar et al., 2019) of NMDA receptors alters the interaction with $\alpha_{2} \delta-1$ and modulation by gabapentinoid drugs. However, a recent paper (Huang et al., 2020) indicates that increased NMDA receptor phosphorylation in spinal cord enhances the amount of $\alpha_{2} \delta$-1 bound NMDA receptor protein and also increases the gabapentin sensitivity of NMDA receptors.

\section{Upregulation of $\alpha_{2} \delta-1$ and NMDA Receptor Function After Neuropathic Injury}

It has been known for 20 years that spinal $\alpha_{2} \delta$-1 protein is markedly upregulated after peripheral nerve injury and that this upregulation causes neuropathic pain symptoms in animal models (Luo et al., 2001; Boroujerdi et al., 2011; Gong et al., 2018). More recently, electron microscopy has revealed that the change in $\alpha_{2} \delta$-1 density occurs primarily in presynaptic sensory neurons rather than postsynaptic dendrites (Bauer et al., 2009) (Fig. 3). That change is accompanied by increased spinal neuron responses to application of NMDA and also by increases in the frequency of glutamate-dependent miniature synaptic potentials in dorsal horn sensory neurons (Chen et al., 2018). Both the increased NMDA receptormediated responses and increased NMDA receptor-mediated miniature synaptic potentials are blocked by acute application of gabapentin or pregabalin. Therefore, in at least some models of neuropathic pain, there is both upregulation of $\alpha_{2} \delta$-1 protein and upregulation of NMDA receptor function in the spinal cord.

\section{Neurexin- $1 \alpha$ as an Additional Target of Gabapentinoids}

Neurexins are a family of presynaptic proteins that protrude from presynaptic terminals into the extracellular space and that have diverse functions in different neuron types. The neurexins are expressed both as full-length membranespanning protein ( $\alpha$-neurexin) and truncated ( $\beta$-neurexin) versions. Neurexins form an important part of the transsynaptic network that modulates synapse functions (Sudhof, 2017). Neurexins prominently bind to postsynaptic proteins of the neuroligin family (Miller et al., 2011) to stabilize and spatially align pre-and postsynaptic elements. Both proteins 

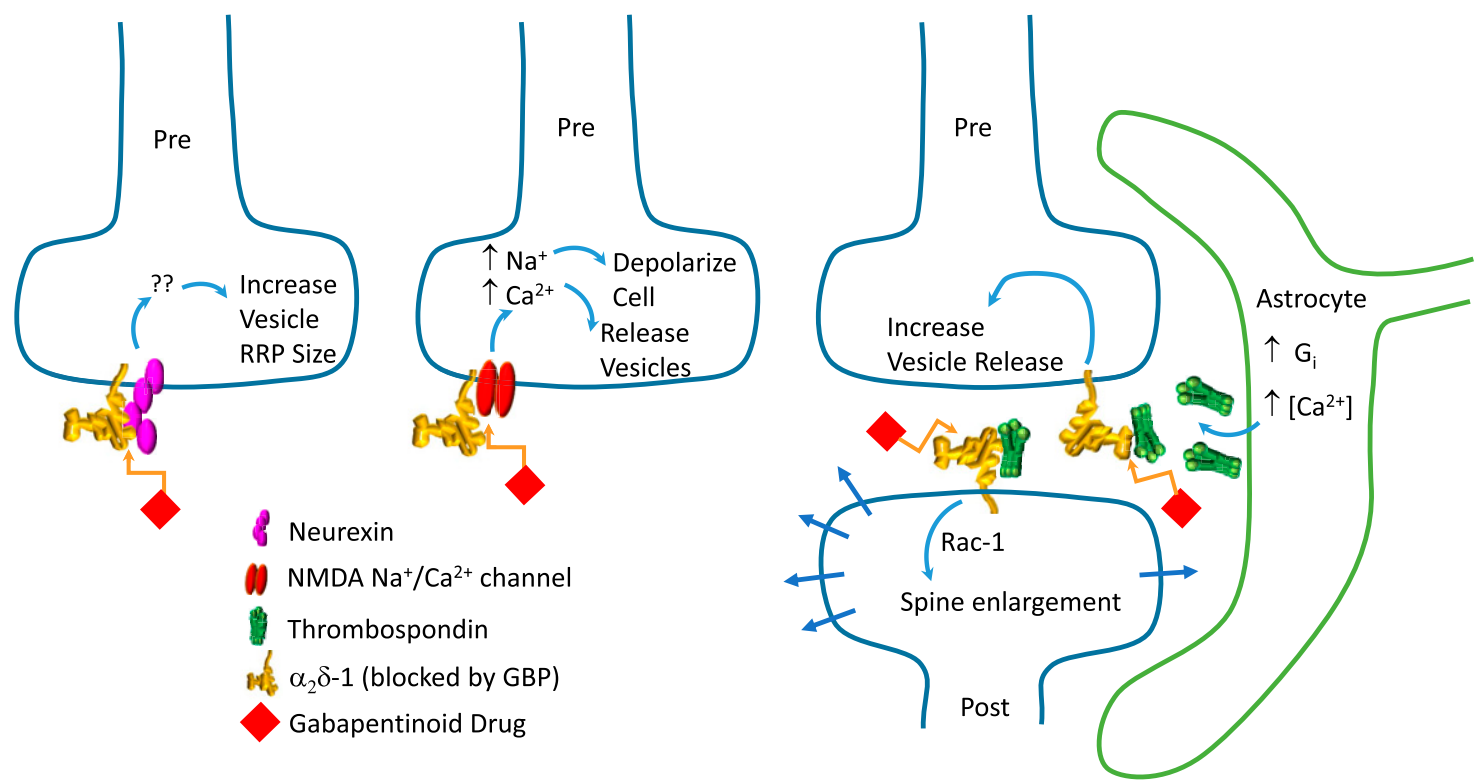

Fig. 4. Proposed gabapentin-sensitive interactions of $\alpha_{2} \delta-1$ with synaptic proteins other than calcium channels. (A) Gabapentin interferes with $\alpha$-neurexin at synapses in model cells to reduce the size of the readily releasable pool (RRP) of presynaptic vesicles (Martínez San Segundo et al., 2020), (B) Gabapentin interferes with the action of presynaptic NMDA receptors in several systems (Chen et al., 2018, 2019; Luo et al., 2018; Ma et al., 2018; Zhou et al., 2018; Deng et al., 2019) to reduce the spontaneous release of synaptic vesicles and decrease NMDA receptor function. (C) Gabapentin interferes with the action of thrombospondin from astrocytes, and this reduces presynaptic vesicle release and also reduces postsynaptic spine enlargement (Risher et al., 2018; Wang et al., 2020). The effect of gabapentin to prevent spine enlargement is mediated by the small Rho GTPase protein, Rac-1, and requires activation of Rac-1 by guanine exchange factors and also requires NMDA receptors. This process then activates the actin cytoskeleton.

interact with a large number of other synaptic scaffolds, postsynaptic receptors, and presynaptic proteins (Biederer et al., 2017; Sudhof, 2017).

Cell cultures of neurons lacking native neurexins have reduced synaptic calcium influx and transmitter release that is restored by $\alpha$-neurexin expression. Surprisingly, this effect of $\alpha$-neurexin to enhance synaptic function appears to be mediated by a weak interaction between neurexin and $\alpha_{2} \delta-1$, at least in one model system (Brockhaus et al., 2018). Interestingly, these effects of $\alpha_{2} \delta$-1 on neurexin function did not appear to be mediated by a stable protein-protein interaction but, rather, by a somewhat weak and transient interaction (Brockhaus et al., 2018).

More recently, it was shown that the soluble extracellular domain of neurexin- $1 \alpha$ reduces radioligand binding of $\left[{ }^{3} \mathrm{H}\right]$ gabapentin to recombinant $\alpha_{2} \delta$-1, indicating a direct interaction between the two proteins (Martínez San Segundo et al., 2020). Functional studies of this interaction were done with a model synapse system cultured in vitro. Microcultures of individual rat superior cervical autonomic neurons form monosynaptic acetylcholine synapses back onto themselves when grown in this manner. These "autaptic" synapses were studied using electrophysiology and presynaptic calcium imaging of synaptic boutons. Application of pregabalin (30 $\mu \mathrm{M})$ reproducibly and reversibly reduced neurotransmitter release by about $50 \%$, as measured by postsynaptic current. The pregabalin effect was particularly pronounced in response to rapid trains of presynaptic action potentials, and these measurements indicated that pregabalin reduced the size of the "readily releasable pool" of synaptic vesicles (Rosenmund and Stevens, 1996; Kaeser and Regehr, 2017). Importantly, the effect of pregabalin was entirely independent of changes in the function of presynaptic voltage-gated calcium channels, since presynaptic calcium influx (measured by a fluorescent indicator) was unchanged. Finally, it was shown that extracellular application of a soluble fragment of neurexin- $1 \alpha$ reduced neurotransmitter release to the same extent as pregabalin and occluded the effects of pregabalin, suggesting that pregabalin and neurexin alter synapse function through the same molecular pathway.

This investigation (Martínez San Segundo et al., 2020) was aided by several technical advantages over other studies of gabapentinoids. The hardiness of autonomic ganglion neurons allowed long-term recordings of synaptic currents without much postsynaptic receptor plasticity (a complicating factor at hippocampal synapses, for example). This allowed estimation of the time course of drug effects (onset time of about 5 minutes and washout time constant of about 50 minutes) and straightforward estimation of readily releasable pool size. The use of a genetically coded presynaptic calcium indicator was possible since only synapses from a single cell were present in each microculture. These results show that, at least in this model system, pregabalin reduces synaptic strength by reducing the readily releasable pool via an interaction between $\alpha_{2} \delta-1$ and presynaptic $\alpha$-neurexin, without any change in the function of presynaptic calcium channels. It will require additional work to establish whether the changes mediated by neurexin are relevant for analgesia by gabapentinoid drugs.

\section{Thrombospondins as an Additional Target of Gabapentinoids}

Thrombospondins are a family of extracellular matrix proteins [reviewed in Risher and Eroglu (2012)] that in the brain are formed mostly by astrocytes. Astrocytes, both in 
spinal cord and neocortex, are thought to play a major role in the pathogenesis of chronic pain (Hansen and Malcangio, 2013). Thrombospondins are released from astroctyes into the extracellular space in response to several stimuli, including activation of glial P2X purinergic gated ion channel receptors (Tran and Neary, 2006; Kim et al., 2016) that respond to ATP from damaged cells or are released from nearby glial calcium waves (Guthrie et al., 1999; Haydon and Carmignoto, 2006). The P2X purinergic gated ion channel receptor family play a significant role in chronic pain (Chizh and Illes, 2001). The $\alpha_{2} \delta$-1 protein was shown to interact with thrombospondin (particularly subtypes 1 and 4) by immunoprecipitation (Eroglu et al., 2009) and by interaction between purified proteins (Park et al., 2016, 2018) (see Table 1). However, two separate studies have failed to show that gabapentin directly disrupts the molecular interaction between thrombospondin and $\alpha_{2} \delta$-1 proteins in vitro (Lana et al., 2016; El-Awaad et al., 2019), suggesting that the inhibition by gabapentin of thrombospondin actions could be indirect or require the presence of other proteins. Additional studies suggest that signaling proteins, including the scaffolding protein LRP1 (Kadurin et al., 2017) or activation of the small Rho GTPase, Ras-related C3 botulinum toxin substrate 1 (Rac1), are part of the biochemical pathway involved in the synaptogenic action that is inhibited by gabapentinoid drugs (Risher et al., 2018). Interestingly, LRP1 also was found to interact with $\beta 1$ integrins at the cell surface to regulate their function (Theret et al., 2017).

Gabapentin and pregabalin inhibit several thrombospondin effects via $\alpha_{2} \delta-1$ and prevent the formation of new synapses in response to thrombospondin application or astroctye activation. It has been known for some time that astrocyteconditioned media promote the formation of new glutamate synapses in cultured neurons, and it was found that this occurs because $\alpha_{2} \delta$-1 proteins act as neuronal thrombospondin receptors (Eroglu et al., 2009). After neuropathic sensory nerve injury (Kim et al., 2012) or spinal cord injury (Zheng et al., 2005), thrombospondin induces chronic-pain-like states and increases the number of excitatory synapses and the rate of glutamatergic mEPSCs in spinal dorsal horn in animal models (Nguyen et al., 2009; Kim et al., 2012).

The newly formed synapses in response to thrombospondin are initially silent glutamate synapses (with NMDA receptors but no functional $\alpha$-amino-3-hydroxy-5-methyl-4-isoxazolepropionic acid type glutamate receptors) (Eroglu et al., 2009; Risher et al., 2018; Yu et al., 2018; Wang et al., 2020). Recent findings indicate that pain-related responses in mice from overexpression of either $\alpha_{2} \delta$ - 1 or thrombospondin- 4 can be acutely blocked with gabapentin or pregabalin (Park et al., 2016) and also with a peptide fragment that prevents the interaction between $\alpha_{2} \delta$-1 and thrombospondin; this peptide also blocks analgesia with pregabalin in a spinal nerve injury model in vivo (Park et al., 2018). Although repeated treatment with gabapentinoids reduces the formation of new synapses induced by thrombospondin, once new synapses formed, gabapentin applied subsequently did not reduce the number or size of synapses but did effectively reduce pain-related behaviors. Therefore, there appear to be two distinct functions of drugs acting at $\alpha_{2} \delta$-1/thrombospondin: one long-lasting, involving synaptic size, and the other more rapid and reversible, acutely reducing painrelated behaviors.
The effects of thrombospondin to promote chronic-pain-like states are prevented by repeated doses of gabapentin acting at $\alpha_{2} \delta$-1 either in the spinal cord (Crosby et al., 2015; Pan et al., 2015; Park et al., 2016) or in the somatosensory cortex (Kim et al., 2016). A separate study showed that thrombospondin-4 application to isolated sensory (dorsal root ganglion) neurons for 4 hours alters voltage-gated calcium currents recorded at the cell body (Pan et al., 2016a). Although gabapentin itself did not acutely reduce voltage-gated calcium currents in these cells, it did prevent the long-term effects of thrombospondin-4 to decrease high-voltage activated currents and increase lowvoltage activated currents. These results strongly suggest that some actions of gabapentinoid drugs to reduce chronic pain may be independent of reducing calcium channel function.

The idea that a thrombospondin- $\alpha_{2} \delta-1$ interaction might underlie gabapentinoid drug actions other than analgesia in chronic pain has also been studied. Repeated prophylactic gabapentin treatment in models of post-traumatic epilepsy ( $\mathrm{Li}$ et al., 2012; Andresen et al., 2014; Lau et al., 2017; Takahashi et al., 2018) prevented the stabilization of abnormal new synapses in neocortex, presumably by blocking the action of astrocyte-derived thrombospondin.

A recent study in the striatum of mice showed that selective stimulation of astrocytes caused the formation of new and stronger glutamate synapses onto striatal medium spiny neurons. This synaptogenesis was mediated by glial-derived thrombospondin-1 acting at $\alpha_{2} \delta$-1, whose effects were blocked by gabapentin (Nagai et al., 2019). The formation of stronger synapses in striatum was associated with behavioral hyperactivity and disrupted attention, and these abnormal behaviors were also prevented by repeated prophylactic gabapentin treatment. An additional study in mice shows that in the nucleus accumbens shell (an area implicated in drug addiction), cocaine administration triggers the formation of new silent glutamate synapses via thrombospondin-2, and this process is blocked by repeated gabapentin administration acting at $\alpha_{2} \delta$-1 (Wang et al., 2020). Finally, an important study (Risher et al., 2018) shows that in mouse neocortex, repeated gabapentin treatment reduces the normal formation of new corticocortical synapses by thrombospondin, and this occurs by a postsynaptic interaction between thrombospondin and $\alpha_{2} \delta$-1, which requires both NMDA receptors and the GTPase Rac1. In this study, activation of the thrombospondin- $\alpha_{2} \delta-1$ pathway had no effect on GABA synapses. Finally, a recent study (https://ssrn.com/abstract=3470401) shows that prophylactic treatment with gabapentin in an animal model of spinal cord injury prevents plasticity in spinal autonomic circuits that cause autonomic dysreflexia by preventing thrombospondin-induced changes.

In summary, $\alpha_{2} \delta$ drugs may prevent the stabilization of new or stronger glutamate synapses formed specifically in response to astrocyte activation and the subsequent release of thrombospondin. This astrocyte-activated process of synaptic strengthening may occur in response to neuronal damage in neocortex (from release of glutamate, potassium ions, and ATP), by sustained astrocyte activation via $\mathrm{GABA}_{\mathrm{B}}$ receptors in striatum, by neuronal activation by cocaine in nucleus accumbens, and also by normal activation of glia during synaptogenesis. Each of these processes appears to activate astrocytes and strengthen nearby glutamate synapses in a process that is blocked by gabapentinoid drugs. It seems likely that the interaction between gabapentinoid drugs and 
thrombospondin function may be relevant for preventing longlasting pain-related anatomic changes. It is less clear that the interaction between $\alpha_{2} \delta$-1 and thrombospondin is necessary for short-lasting analgesia from acute treatment with gabapentinoid drugs in some animal models or clinical use.

\section{Other $\alpha_{2} \delta-1$ Binding Proteins}

BK-type voltage-gated potassium channels compete with voltage-gated calcium channel $\alpha 1$ subunits for $\alpha_{2} \delta$-1 protein binding (Zhang et al., 2018). BK channels directly associate with $\mathrm{Ca}_{\mathrm{V}} 2.1$ and $\mathrm{Ca}_{\mathrm{V}} 2.2$ channels at presynaptic endings in brain (Berkefeld et al., 2006; Dai et al., 2009), putting them within a few nanometers of vesicle release machinery at synapses. This localization is required for BK channel function to rapidly hyperpolarize cells in response to presynaptic calcium influx and to moderate calcium-induced vesicle release. Although not studied by protein-protein interaction techniques, recent findings (Hoppa et al., 2014) indicate that changes in $\alpha_{2} \delta$-1 expression in cultured neurons alter the function of presynaptic $K_{\mathrm{V}} 1$ and $\mathrm{K}_{\mathrm{V}} 3.1$ potassium channels. To date, no studies of gabapentin or pregabalin have been published on $\mathrm{BK}$ channel function or $\mathrm{K}_{\mathrm{V}} 1 / \mathrm{K}_{\mathrm{V}} 3.1$ channel function at synaptic endings.

Brain $\alpha_{2} \delta$-1 also interacts directly with the membranebound protein trafficking molecule LRP1, a transmembrane protein that is involved in mediating $\alpha_{2} \delta$ - 1 effects on calcium channel traffic to and from the membrane (Kadurin et al., 2017). LRP1 has many protein-interacting domains and is known to interact with a variety of other proteins (Lillis et al., 2008), including the extracellular matrix proteins fibronectin and thrombospondin; apolipoprotein E; and intracellular proteins such as RAP, Shc (Src homology and collagen family of adaptor proteins), protein kinase C, PSD-95 (post-synaptic density protein of $95 \mathrm{kD} \mathrm{MW}$, which plays an important role with postsynaptic NMDA receptors), and the endoplasmic reticulum protein calreticulin. Calreticulin is involved in protein processing in endosomes. It is possible that LRP1 participates in the interaction between $\alpha_{2} \delta$-1 and thrombospondin or other proteins like the cell signaling protein RAC1 (Risher et al., 2018).

There is evidence that $\alpha_{2} \delta$-1 interacts with several other proteins in brain (Table 2), although many of these interactions are very likely indirect, particularly those involving presynaptic vesicle release proteins that are known to directly interact with calcium channel $\alpha_{1}$ subunits [reviewed in He et al. (2018)].

\section{Summary and Conclusions}

Since the discovery of the analgesic activity of gabapentin, identifying its mechanism of action at the cellular level has been challenging, with many promising and plausible, but apparently false, leads. It is now clear that, although the analgesic effects of gabapentin-like drugs involve an interaction with $\alpha_{2} \delta$-1, those effects clearly are not limited to voltagegated calcium channels. Instead, there is compelling new evidence that several gabapentinoid drug effects involve other proteins that interact with $\alpha_{2} \delta$-1, specifically a subset of NMDA receptors, neurexin-1 $\alpha$, and thrombospondins (Fig. 4).

Interactions between $\alpha_{2} \delta$-1 and neurexins could explain at least part of the gabapentinoid drug's ability to reduce neurotransmitter release from neocortical and hippocampal tissues, where there is not always a clear correlation between neurotransmitter release and decreased calcium channel function. In light of the findings reviewed here about interactions of $\alpha_{2} \delta$-1 with multiple synaptic proteins and findings that overexpression of $\alpha_{2} \delta$-1 in cultured neocortical neurons actually decrease presynaptic calcium influx (Hoppa et al., $2012,2014)$, it seems likely that synaptic proteins other than calcium channel $\alpha 1$ subunits may be required for gabapentinoid drugs to reduce mEPSC frequency and excitatory neurotransmitter release.

The interaction between $\alpha_{2} \delta-1$ and NMDA receptors is particularly intriguing because NMDA receptors have long been seen as promising targets for analgesic and antiseizure drugs but have proven elusive in terms of drugs with favorable risk/benefit profiles. Although gabapentin and pregabalin clearly do not modulate all NMDA receptors, it is also clear that some subsets of NMDA receptors are modulated by drug binding to $\alpha_{2} \delta$-1. The interaction of thrombospondins with $\alpha_{2} \delta$ 1 may also be important for some pharmacological actions of gabapentin and pregabalin, particularly when pain is augmented by activation of glia that release thrombospondin to form new and enlarged glutamate synapses.

An important unanswered question with gabapentinoid drugs is whether different proteins can interact at $\alpha_{2} \delta-1$ at the same time or whether such interactions are mutually exclusive. In this regard, one study has shown that BK potassium channels compete with calcium channel $\alpha_{1}$ subunits for binding $\alpha_{2} \delta$-1. However, it is not yet known whether $\alpha_{2} \delta$ - 1 interactions with thrombospondins, NMDA receptors, or neurexins are mutually exclusive with each other or with calcium channel $\alpha_{1}$ proteins. An important step in this direction was provided by findings that a GPI anchor at the membrane portion of $\alpha_{2} \delta$-1 is required for increasing cellular calcium currents (Davies et al., 2010), but a similar modification prevents the $\alpha_{2} \delta$-1/thrombospondin action that enlarges synaptic spines (Risher et al., 2018). Furthermore, a fulllength and apparently membrane-spanning $\alpha_{2} \delta$-1 is required for $\alpha_{2} \delta$-1-NMDA receptor interactions (Chen et al., 2018). Thus, differently processed $\alpha_{2} \delta$-1 proteins are required for some of the different gabapentinoid drug functions in neurons.

In conclusion, although gabapentinoids do appear to act by binding to $\alpha_{2} \delta$-1, analgesic effects appear to involve not only voltage-gated calcium channels but also other proteins, including a subset of NMDA receptors, neurexins, thrombospondins, and possibly other proteins. In particular, existing evidence suggests the $\alpha_{2} \delta$-1-thrombospondin interaction independent of calcium channels may be important for gabapentinoid drugs to reduce long-lasting pain with only acute treatment around the time of nerve injury.

\section{Acknowledgments}

The authors are grateful to many people who have studied gabapentin, pregabalin, and their binding sites and physiological mechanisms over the past 30 years and to anonymous reviewers of an earlier version of the manuscript.

\section{Authorship Contributions}

Wrote or contributed to the writing of the manuscript: Taylor, Harris.

\section{References}

Abrahamsson T, Chou CYC, Li SY, Mancino A, Costa RP, Brock JA, Nuro E, Buchanan KA, Elgar D, Blackman AV, et al. (2017) Differential regulation of 
evoked and spontaneous release by presynaptic NMDA receptors. Neuron 96: 839-855.e5.

Alles SRA, Bandet MV, Eppler K, Noh MC, Winship IR, Baker G, Ballanyi K, and Smith PA (2017) Acute anti-allodynic action of gabapentin in dorsal horn and primary somatosensory cortex: correlation of behavioural and physiological data. Neuropharmacology 113:576-590.

Alvarez-Laviada A, Kadurin I, Senatore A, Chiesa R, and Dolphin AC (2014) The inhibition of functional expression of calcium channels by prion protein demonstrates competition with $\alpha 2 \delta$ for GPI-anchoring pathways. Biochem $J$ 458:365-374

Andresen L, Hampton D, Taylor-Weiner A, Morel L, Yang Y, Maguire J, and Dulla CG (2014) Gabapentin attenuates hyperexcitability in the freeze-lesion model of developmental cortical malformation. Neurobiol Dis 71:305-316.

Banerjee A, Larsen RS, Philpot BD, and Paulsen O (2016) Roles of presynaptic NMDA receptors in neurotransmission and plasticity. Trends Neurosci 39:26-39.

Bannister K, Qu C, Navratilova E, Oyarzo J, Xie JY, King T, Dickenson AH, and Porreca F (2017) Multiple sites and actions of gabapentin-induced relief of ongoing experimental neuropathic pain. Pain 158:2386-2395.

Bauer CS, Nieto-Rostro M, Rahman W, Tran-Van-Minh A, Ferron L, Douglas L, Kadurin I, Sri Ranjan Y, Fernandez-Alacid L, Millar NS, et al. (2009) The increased trafficking of the calcium channel subunit alpha2delta-1 to presynaptic terminals in neuropathic pain is inhibited by the alpha2delta ligand pregabalin. J Neurosci 29:4076-4088.

Berberich S, Punnakkal P, Jensen V, Pawlak V, Seeburg PH, Hvalby Ø, and Köhr G (2005) Lack of NMDA receptor subtype selectivity for hippocampal long-term potentiation. $J$ Neurosci 25:6907-6910.

Berkefeld H, Sailer CA, Bildl W, Rohde V, Thumfart JO, Eble S, Klugbauer N, Reisinger E, Bischofberger J, Oliver D, et al. (2006) BKCa-Cav channel complexes mediate rapid and localized $\mathrm{Ca} 2+-$ activated $\mathrm{K}+$ signaling. Science 314:615-620.

Bian F, Li Z, Offord J, Davis MD, McCormick J, Taylor CP, and Walker LC (2006) Calcium channel alpha $_{2}$-delta type 1 subunit is the major binding protein for pregabalin in neocortex, hippocampus, amygdala, and spinal cord: an ex vivo autoradiographic study in alpha 2 -delta type 1 genetically modified mice. Brain Res 1075:68-80.

Biederer T, Kaeser PS, and Blanpied TA (2017) Transcellular nanoalignment of synaptic function. Neuron 96:680-696.

Boroujerdi A, Zeng J, Sharp K, Kim D, Steward O, and Luo ZD (2011) Calcium channel alpha-2-delta-1 protein upregulation in dorsal spinal cord mediates spinal cord injury-induced neuropathic pain states. Pain 152:649-655.

Bouvier G, Larsen RS, Rodríguez-Moreno A, Paulsen O, and Sjöström PJ (2018) Towards resolving the presynaptic NMDA receptor debate. Curr Opin Neurobiol $\mathbf{5 1}: 1-7$

Briot J, D'Avanzo N, Sygusch J, and Parent L (2016) Three-dimensional architecture of the L-type calcium channel: structural insights into the $\mathrm{CaV} \alpha 2 \delta 1$ auxiliary protein. Biochem $\mathrm{Mol}$ Biol $J \mathbf{2}$

Brockhaus J, Schreitmüller M, Repetto D, Klatt O, Reissner C, Elmslie K, Heine M, and Missler M (2018) $\alpha$-Neurexins together with $\alpha 2 \delta-1$ auxiliary subunits regulate $\mathrm{Ca}^{2+}$ influx through $\mathrm{Ca}_{\mathrm{v}} 2.1$ channels. J Neurosci 38:8277-8294.

Buvanendran A, Kroin JS, Della Valle CJ, Kari M, Moric M, and Tuman KJ (2010) Perioperative oral pregabalin reduces chronic pain after total knee arthroplasty: a prospective, randomized, controlled trial. Anesth Analg 110:199-207.

Cain SM, Bohnet B, LeDue J, Yung AC, Garcia E, Tyson JR, Alles SR, Han H, van den Maagdenberg AM, Kozlowski P, et al. (2017) In vivo imaging reveals that pregabalin inhibits cortical spreading depression and propagation to subcortical brain structures. Proc Natl Acad Sci USA 114:2401-2406.

Cantí C, Nieto-Rostro M, Foucault I, Heblich F, Wratten J, Richards MW, Hendrich J, Douglas L, Page KM, Davies A, et al. (2005) The metal-ion-dependent adhesion site in the Von Willebrand factor-A domain of alpha2delta subunits is key to trafficking voltage-gated Ca2+ channels. Proc Natl Acad Sci USA 102:11230-11235.

Carlson CB, Lawler J, and Mosher DF (2008) Structures of thrombospondins. Cell Mol Life Sci 65:672-686.

Chen J, Li L, Chen SR, Chen H, Xie JD, Sirrieh RE, MacLean DM, Zhang Y, Zhou MH, Jayaraman V, et al. (2018) The $\alpha 2 \delta$-1-NMDA receptor complex is critically involved in neuropathic pain development and gabapentin therapeutic actions. Cell Rep 22:2307-2321.

Chen Y, Chen SR, Chen H, Zhang J, and Pan HL (2019) Increased $\alpha 2 \delta-1-N M D A$ receptor coupling potentiates glutamatergic input to spinal dorsal horn neurons in chemotherapy-induced neuropathic pain. $J$ Neurochem 148:252-274.

Chizh BA and Illes P (2001) P2X receptors and nociception. Pharmacol Rev 53: $553-568$

Clarke H, Bonin RP, Orser BA, Englesakis M, Wijeysundera DN, and Katz J (2012) The prevention of chronic postsurgical pain using gabapentin and pregabalin: a combined systematic review and meta-analysis. Anesth Analg 115:428-442.

Crosby ND, Zaucke F, Kras JV, Dong L, Luo ZD, and Winkelstein BA (2015) Thrombospondin-4 and excitatory synaptogenesis promote spinal sensitization after painful mechanical joint injury. Exp Neurol 264:111-120.

Cunningham MO, Woodhall GL, Thompson SE, Dooley DJ, and Jones RSG (2004) Dual effects of gabapentin and pregabalin on glutamate release at rat entorhinal synapses in vitro. Eur J Neurosci 20:1566-1576.

Dai S, Hall DD, and Hell JW (2009) Supramolecular assemblies and localized regulation of voltage-gated ion channels. Physiol Rev 89:411-452.

Davies A, Douglas L, Hendrich J, Wratten J, Tran Van Minh A, Foucault I, Koch D, Pratt WS, Saibil HR, and Dolphin AC (2006) The calcium channel alpha ${ }_{2}$ delta-2 subunit partitions with $\mathrm{Ca}_{\mathrm{V}} 2.1$ into lipid rafts in cerebellum: implications for localization and function. $J$ Neurosci 26:8748-8757.

Davies A, Kadurin I, Alvarez-Laviada A, Douglas L, Nieto-Rostro M, Bauer CS, Pratt WS, and Dolphin AC (2010) The alpha2delta subunits of voltage-gated calcium channels form GPI-anchored proteins, a posttranslational modification essential for function. Proc Natl Acad Sci USA 107:1654-1659.

Deng M, Chen SR, Chen H, and Pan HL (2019) $\alpha 2 \delta$-1-Bound N-Methyl-D-aspartate receptors mediate morphine-induced hyperalgesia and analgesic tolerance by potentiating glutamatergic input in rodents. Anesthesiology 130:804-819.
Di Guilmi MN, Urbano FJ, Inchauspe CG, and Uchitel OD (2011) Pregabalin modulation of neurotransmitter release is mediated by change in intrinsic activation/ inactivation properties of ca(v) 2.1 calcium channels. J Pharmacol Exp Ther $\mathbf{3 3 6}$ 973-982.

Dolphin AC (2013) The $\alpha 2 \delta$ subunits of voltage-gated calcium channels. Biochim Biophys Acta 1828:1541-1549.

Dolphin AC (2016) Voltage-gated calcium channels and their auxiliary subunits: physiology and pathophysiology and pharmacology. J Physiol 594:5369-5390.

Dolphin AC (2018) Voltage-gated calcium channel $\alpha{ }_{2} \delta$ subunits: an assessment of proposed novel roles. F1000 Res 7:F1000 Faculty Rev-1830.

Domon Y, Arakawa N, Inoue T, Matsuda F, Takahashi M, Yamamura N, Kai K, and Kitano Y (2018) Binding characteristics and analgesic effects of mirogabalin, a novel ligand for the $\alpha_{2} \delta$ subunit of voltage-gated calcium channels. $J$ Pharmacol Exp Ther 365:573-582.

Dooley DJ, Taylor CP, Donevan S, and Feltner D (2007) $\mathrm{Ca}^{2+}$ channel $\alpha_{2} \delta$ ligands: novel modulators of neurotransmission. Trends Pharmacol Sci 28:75-82.

Dore K, Stein IS, Brock JA, Castillo PE, Zito K, and Sjöström PJ (2017) Unconventional NMDA receptor signaling. J Neurosci 37:10800-10807.

El-Awaad E, Pryymachuk G, Fried C, Matthes J, Isensee J, Hucho T, Neiss WF, Paulsson M, Herzig S, Zaucke F, et al. (2019) Direct, gabapentin-insensitive interaction of a soluble form of the calcium channel subunit $\alpha_{2} \delta-1$ with thrombospondin-4. Sci Rep 9:16272.

Eroglu C, Allen NJ, Susman MW, O'Rourke NA, Park CY, Ozkan E, Chakraborty C, Mulinyawe SB, Annis DS, Huberman AD, et al. (2009) Gabapentin receptor alpha2delta-1 is a neuronal thrombospondin receptor responsible for excitatory CNS synaptogenesis. Cell 139:380-392.

Fehrenbacher JC, Taylor CP, and Vasko MR (2003) Pregabalin and gabapentin reduce release of substance $\mathrm{P}$ and CGRP from rat spinal tissues only after inflammation or activation of protein kinase C. Pain 105:133-141.

Felix R, Gurnett CA, De Waard M, and Campbell KP (1997) Dissection of functional domains of the voltage-dependent $\mathrm{Ca} 2+$ channel alpha2delta subunit. $J$ Neurosci 17:6884-6891.

Ferron L, Kadurin I, and Dolphin AC (2018) Proteolytic maturation of $\alpha_{2} \delta$ controls the probability of synaptic vesicular release. eLife 7:e37507.

Field MJ, Cox PJ, Stott E, Melrose H, Offord J, Su TZ, Bramwell S, Corradini L, England S, Winks J, et al. (2006) Identification of the alpha2-delta-1 subunit of voltage-dependent calcium channels as a molecular target for pain mediating the analgesic actions of pregabalin. Proc Natl Acad Sci USA 103: $17537-17542$

Field MJ, Holloman EF, McCleary S, Hughes J, and Singh L (1997) Evaluation of gabapentin and S-(+)-3-isobutylgaba in a rat model of postoperative pain. $J$ Pharmacol Exp Ther 282:1242-1246.

García K, Nabhani T, and García J (2008) The calcium channel alpha2/delta1 subunit is involved in extracellular signalling. $J$ Physiol 586:727-738.

Gee NS, Brown JP, Dissanayake VU, Offord J, Thurlow R, and Woodruff GN (1996 The novel anticonvulsant drug, gabapentin (Neurontin), binds to the alpha $a_{2}$ delta subunit of a calcium channel. J Biol Chem 271:5768-5776.

Geisler S, Schöpf CL, Stanika R, Kalb M, Campiglio M, Repetto D, Traxler L, Missler M, and Obermair GJ (2019) Presynaptic $\alpha_{2} \delta-2$ calcium channel subunits regulate postsynaptic $\mathrm{GABA}_{\mathrm{A}}$ receptor abundance and axonal wiring. $J$ Neurosci $\mathbf{3 9}$ 2581-2605

Gilron I (2007) Gabapentin and pregabalin for chronic neuropathic and early postsurgical pain: current evidence and future directions. Curr Opin Anaesthesiol 20 456-472.

Ginsberg MH, Partridge A, and Shattil SJ (2005) Integrin regulation. Curr Opin Cell Biol 17:509-516.

Gong N, Park J, and Luo ZD (2018) Injury-induced maladaptation and dysregulation of calcium channel $\alpha_{2} \delta$ subunit proteins and its contribution to neuropathic pain development. Br J Pharmacol 175:2231-2243.

Groffen AJ, Martens S, Díez Arazola R, Cornelisse LN, Lozovaya N, de Jong AP, Goriounova NA, Habets RL, Takai Y, Borst JG, et al. (2010) Doc2b is a high-affinity $\mathrm{Ca} 2+$ sensor for spontaneous neurotransmitter release. Science 327:1614-1618.

Gu Y and Huang LY (2001) Gabapentin actions on N-methyl-D-aspartate receptor channels are protein kinase C-dependent. Pain 93:85-92.

Gu Y and Huang LY (2002) Gabapentin potentiates N-methyl-D-aspartate receptor mediated currents in rat GABAergic dorsal horn neurons. Neurosci Lett 324: $177-180$.

Gurnett CA, De Waard M, and Campbell KP (1996) Dual function of the voltagedependent $\mathrm{Ca}^{2+}$ channel $\alpha 2 \delta$ subunit in current stimulation and subunit interaction. Neuron 16:431-440.

Gurnett CA, Felix R, and Campbell KP (1997) Extracellular interaction of the voltage-dependent $\mathrm{Ca} 2+$ channel $\alpha 2 \delta$ and $\alpha 1$ subunits. J Biol Chem 272: 18508-18512.

Guthrie PB, Knappenberger J, Segal M, Bennett MV, Charles AC, and Kater SB (1999) ATP released from astrocytes mediates glial calcium waves. J Neurosci 19 $520-528$

Hansen RR and Malcangio M (2013) Astrocytes--multitaskers in chronic pain. Eur $J$ Pharmacol 716:120-128.

Hara K and Sata T (2007) Inhibitory effect of gabapentin on N-methyl-D-aspartate receptors expressed in Xenopus oocytes. Acta Anaesthesiol Scand 51:122-128.

Haydon PG and Carmignoto G (2006) Astrocyte control of synaptic transmission and neurovascular coupling. Physiol Rev 86:1009-1031.

He R, Zhang J, Yu Y, Jizi L, Wang W, and Li M (2018) New insights into interactions of presynaptic calcium channel subtypes and SNARE proteins in neurotransmitter release. Front Mol Neurosci 11:213.

Heblich F, Tran Van Minh A, Hendrich J, Watschinger K, and Dolphin AC (2008 Time course and specificity of the pharmacological disruption of the trafficking of voltage-gated calcium channels by gabapentin, Channels (Austin) 2, pp 4-9.

Hendrich J, Van Minh AT, Heblich F, Nieto-Rostro M, Watschinger K, Striessnig J, Wratten J, Davies A, and Dolphin AC (2008) Pharmacological disruption of calcium 
channel trafficking by the alpha ${ }_{2}$ delta ligand gabapentin. Proc Natl Acad Sci USA 105:3628-3633.

Hoppa MB, Gouzer G, Armbruster M, and Ryan TA (2014) Control and plasticity of the presynaptic action potential waveform at small CNS nerve terminals. Neuron 84:778-789.

Hoppa MB, Lana B, Margas W, Dolphin AC, and Ryan TA (2012) $\alpha 2 \delta$ expression sets presynaptic calcium channel abundance and release probability. Nature 486:122-125.

Huang Y, Chen SR, Chen H, Luo Y, and Pan HL (2020) Calcineurin inhibition causes $\alpha 2 \delta$-1-mediated tonic activation of synaptic NMDA receptors and pain hypersensitivity. J Neurosci [published ahead of print].

Jun JH and Yaksh TL (1998) The effect of intrathecal gabapentin and 3-isobutyl gamma-aminobutyric acid on the hyperalgesia observed after thermal injury in the rat. Anesth Analg 86:348-354.

Kadurin I, Ferron L, Rothwell SW, Meyer JO, Douglas LR, Bauer CS, Lana B, Margas W, Alexopoulos O, Nieto-Rostro M, et al. (2016) Proteolytic maturation of $\alpha_{2} \delta$ represents a checkpoint for activation and neuronal trafficking of latent calcium channels. eLife 5:e21143.

Kadurin I, Rothwell SW, Lana B, Nieto-Rostro M, and Dolphin AC (2017) LRP1 influences trafficking of N-type calcium channels via interaction with the auxiliary $\alpha_{2} \delta$-1 subunit. Sci Rep 7:43802.

Kaeser PS and Regehr WG (2017) The readily releasable pool of synaptic vesicles. Curr Opin Neurobiol 43:63-70.

Karakas E and Furukawa H (2014) Crystal structure of a heterotetrameric NMDA receptor ion channel. Science 344:992-997.

Kim DS, Li KW, Boroujerdi A, Peter Yu Y, Zhou CY, Deng P, Park J, Zhang X, Lee J, Corpe M, et al. (2012) Thrombospondin-4 contributes to spinal sensitization and neuropathic pain states. J Neurosci 32:8977-8987.

Kim SK, Hayashi H, Ishikawa T, Shibata K, Shigetomi E, Shinozaki Y, Inada H, Roh SE, Kim SJ, Lee G, et al. (2016) Cortical astrocytes rewire somatosensory cortical circuits for peripheral neuropathic pain. J Clin Invest 126:1983-1997.

Kotev M, Pascual R, Almansa C, Guallar V, and Soliva R (2018) Pushing the limits of computational structure-based drug design with a cryo-EM structure: the $\mathrm{Ca}^{2+}$ channel $\alpha 2 \delta-1$ subunit as a test case. $J$ Chem Inf Model 58:1707-1715.

Kreutzwiser D and Tawfic QA (2019) Expanding role of NMDA receptor antagonists in the management of pain. CNS Drugs 33:347-374.

Lana B, Page KM, Kadurin I, Ho S, Nieto-Rostro M, and Dolphin AC (2016) Thrombospondin-4 reduces binding affinity of $[(3) \mathrm{H}]$-gabapentin to calciumchannel $\alpha 2 \delta$-1-subunit but does not interact with $\alpha 2 \delta$-1 on the cell-surface when co-expressed. Sci Rep 6:24531.

Lana B, Schlick B, Martin S, Pratt WS, Page KM, Goncalves L, Rahman W, Dickenson AH, Bauer CS, and Dolphin AC (2014) Differential upregulation in DRG neurons of an $\alpha 2 \delta-1$ splice variant with a lower affinity for gabapentin after peripheral sensory nerve injury. Pain 155:522-533.

Larsen RS, Corlew RJ, Henson MA, Roberts AC, Mishina M, Watanabe M, Lipton SA, Nakanishi N, Pérez-Otaño I, Weinberg RJ, et al. (2011) NR3A-containing NMDARs promote neurotransmitter release and spike timing-dependent plasticity. Nat Neurosci 14:338-344.

Lau LA, Noubary F, Wang D, and Dulla CG (2017) $\alpha 2 \delta-1$ signaling drives cell death synaptogenesis, circuit reorganization, and gabapentin-mediated neuroprotection in a model of insult-induced cortical malformation. eNeuro 4:ENEURO.0316-17.2017.

Li CY, Song YH, Higuera ES, and Luo ZD (2004) Spinal dorsal horn calcium channel alpha2delta-1 subunit upregulation contributes to peripheral nerve injury-induced tactile allodynia. J Neurosci 24:8494-8499.

Li CY, Zhang XL, Matthews EA, Li KW, Kurwa A, Boroujerdi A, Gross J, Gold MS, Dickenson AH, Feng G, et al. (2006) Calcium channel alpha2delta1 subunit mediates spinal hyperexcitability in pain modulation. Pain 125:20-34.

Li H, Deng Y, Sun K, Yang H, Liu J, Wang M, Zhang Z, Lin J, Wu C, Wei Z, et al. (2017) Structural basis of kindlin-mediated integrin recognition and activation. Proc Natl Acad Sci USA 114:9349-9354.

Li H, Graber KD, Jin S, McDonald W, Barres BA, and Prince DA (2012) Gabapentin decreases epileptiform discharges in a chronic model of neocortical trauma. Neurobiol Dis 48:429-438.

Li KW, Kim DS, Zaucke F, and Luo ZD (2014a) Trigeminal nerve injury-induced thrombospondin-4 up-regulation contributes to orofacial neuropathic pain states in a rat model. Eur J Pain 18:489-495.

Li KW, Yu YP, Zhou C, Kim DS, Lin B, Sharp K, Steward O, and Luo ZD (2014b) Calcium channel $\alpha 2 \delta 1$ proteins mediate trigeminal neuropathic pain states associated with aberrant excitatory synaptogenesis. J Biol Chem 289:7025-7037.

Li YH, Han TZ, and Meng K (2008) Tonic facilitation of glutamate release by glycine binding sites on presynaptic NR2B-containing NMDA autoreceptors in the rat visual cortex. Neurosci Lett 432:212-216.

Li YH, Wang J, and Zhang G (2009) Presynaptic NR2B-containing NMDA autoreceptors mediate gluta-matergic synaptic transmission in the rat visual cortex Curr Neurovasc Res 6:104-109.

Li Z, Taylor CP, Weber M, Piechan J, Prior F, Bian F, Cui M, Hoffman D, and Donevan S (2011) Pregabalin is a potent and selective ligand for $\alpha(2) \delta-1$ and $\alpha(2) \delta-2$ calcium channel subunits. Eur J Pharmacol 667:80-90.

Lillis AP, Van Duyn LB, Murphy-Ullrich JE, and Strickland DK (2008) LDL receptorrelated protein 1: unique tissue-specific functions revealed by selective gene knockout studies. Physiol Rev 88:887-918.

Liu L, Wong TP, Pozza MF, Lingenhoehl K, Wang Y, Sheng M, Auberson YP, and Wang YT (2004) Role of NMDA receptor subtypes in governing the direction of hippocampal synaptic plasticity. Science 304:1021-1024.

Lotarski S, Hain H, Peterson J, Galvin S, Strenkowski B, Donevan S, and Offord J (2014) Anticonvulsant activity of pregabalin in the maximal electroshock-induced seizure assay in $\alpha 2 \delta 1$ (R217A) and $\alpha 2 \delta 2$ (R279A) mouse mutants. Epilepsy Res 108 833-842.

Lotarski SM, Donevan S, El-Kattan A, Osgood S, Poe J, Taylor CP, and Offord J (2011) Anxiolytic-like activity of pregabalin in the Vogel conflict test in $\alpha 2 \delta-1$ (R217A) and $\alpha 2 \delta-2$ (R279A) mouse mutants. $J$ Pharmacol Exp Ther 338:615-621.
Luo Y, Ma H, Zhou JJ, Li L, Chen SR, Zhang J, Chen L, and Pan HL (2018) Focal cerebral ischemia and reperfusion induce brain injury through $\alpha 2 \delta$-1-bound NMDA receptors. Stroke 49:2464-2472.

Luo ZD, Calcutt NA, Higuera ES, Valder CR, Song YH, Svensson CI, and Myers RR (2002) Injury type-specific calcium channel alpha 2 delta-1 subunit up-regulation in rat neuropathic pain models correlates with antiallodynic effects of gabapentin. $J$ Pharmacol Exp Ther 303:1199-1205.

Luo ZD, Chaplan SR, Higuera ES, Sorkin LS, Stauderman KA, Williams ME, and Yaksh TL (2001) Upregulation of dorsal root ganglion (alpha)2(delta) calcium channel subunit and its correlation with allodynia in spinal nerve-injured rats. J Neurosci 21:1868-1875.

Ma H, Chen SR, Chen H, Zhou JJ, Li DP, and Pan HL (2018) $\alpha 2 \delta-1$ couples to NMDA receptors in the hypothalamus to sustain sympathetic vasomotor activity in hypertension. J Physiol 596:4269-4283.

Maneuf YP and McKnight AT (2001) Block by gabapentin of the facilitation of glutamate release from rat trigeminal nucleus following activation of protein kinase $\mathrm{C}$ or adenylyl cyclase. $\mathrm{Br}$ J Pharmacol 134:237-240.

Martínez San Segundo P, Terni B, Burgueno J, Monroy X, Dordal A, Merlos M, and Llobet A (2020) Outside-in regulation of the readily releasable pool of synaptic vesicles by $\alpha 2 \delta-1$. FASEB $J$ 34:1362-1377.

Matsuzawa R, Fujiwara T, Nemoto K, Fukushima T, Yamaguchi S, Akagawa K and Hori Y (2014) Presynaptic inhibitory actions of pregabalin on excitatory transmission in superficial dorsal horn of mouse spinal cord: further characterization of presynaptic mechanisms. Neurosci Lett 558:186-191.

Micheva KD, Taylor CP, and Smith S.J (2006) Pregabalin reduces the release of synaptic vesicles from cultured hippocampal neurons. Mol Pharmacol 70:467-476. Miller MT, Mileni M, Comoletti D, Stevens RC, Harel M, and Taylor P (2011) The crystal structure of the $\alpha$-neurexin-1 extracellular region reveals a hinge point for mediating synaptic adhesion and function. Structure 19:767-778.

Moore KA, Baba H, and Woolf CJ (2002) Gabapentin-- actions on adult superficial dorsal horn neurons. Neuropharmacology 43:1077-1081.

Murrough JW, Iosifescu DV, Chang LC, Al Jurdi RK, Green CE, Perez AM, Iqbal S, Pillemer S, Foulkes A, Shah A, et al. (2013) Antidepressant efficacy of ketamine in treatment-resistant major depression: a two-site randomized controlled trial. Am J Psychiatry 170:1134-1142.

Nagai J, Rajbhandari AK, Gangwani MR, Hachisuka A, Coppola G, Masmanidis SC, Fanselow MS, and Khakh BS (2019) Hyperactivity with disrupted attention by activation of an astrocyte synaptogenic cue. Cell 177:1280-1292.e20.

Nguyen D, Deng P, Matthews EA, Kim DS, Feng G, Dickenson AH, Xu ZC, and Luo ZD (2009) Enhanced pre-synaptic glutamate release in deep-dorsal horn contributes to calcium channel alpha-2-delta-1 protein-mediated spinal sensitization and behavioral hypersensitivity. Mol Pain 5:6.

Oles RJ, Singh L, Huges J, and Woodruff GN (1990) The anticonvulsant action of gabapentin involves the glycine/NMDA receptor, in Society for Neuroscience Annual Meeting, St. Louis, MO, USA.

Pan B, Guo Y, Wu HE, Park J, Trinh VN, Luo ZD, and Hogan QH (2016a) Thrombospondin-4 divergently regulates voltage-gated $\mathrm{Ca} 2+$ channel subtypes in sensory neurons after nerve injury. Pain 157:2068-2080.

Pan B, Yu H, Park J, Yu YP, Luo ZD, and Hogan QH (2015) Painful nerve injury upregulates thrombospondin-4 expression in dorsal root ganglia. J Neurosci Res 93:443-453.

Pan L, Zhao Y, Yuan Z, and Qin G (2016b) Research advances on structure and biological functions of integrins. Springerplus 5:1094.

Park H, Popescu A, and Poo MM (2014) Essential role of presynaptic NMDA receptors in activity-dependent BDNF secretion and corticostriatal LTP. Neuron 84:1009-1022.

Park J, Yu YP, Zhou CY, Li KW, Wang D, Chang E, Kim DS, Vo B, Zhang X, Gong N, et al. (2016) Central mechanisms mediating thrombospondin-4-induced pain states. J Biol Chem 291:13335-13348.

Park JF, Yu YP, Gong N, Trinh VN, and Luo ZD (2018) The EGF-LIKE domain of thrombospondin-4 is a key determinant in the development of pain states due to increased excitatory synaptogenesis. J Biol Chem 293:16453-16463.

Patel MK, Gonzalez MI, Bramwell S, Pinnock RD, and Lee K (2000) Gabapentin inhibits excitatory synaptic transmission in the hyperalgesic spinal cord. $\mathrm{Br}$ J Pharmacol 130:1731-1734.

Petralia RS, Wang YX, and Wenthold RJ (1994) The NMDA receptor subunits NR2A and NR2B show histological and ultrastructural localization patterns similar to those of NR1. J Neurosci 14:6102-6120.

Prince DA, Gu F, and Parada I (2016) Antiepileptogenic repair of excitatory and inhibitory synaptic connectivity after neocortical trauma. Prog Brain Res 226: 209-227.

Quintero JE, Dooley DJ, Pomerleau F, Huettl P, and Gerhardt GA (2011) Amperometric measurement of glutamate release modulation by gabapentin and pregabalin in rat neocortical slices: role of voltage-sensitive $\mathrm{Ca} 2+\alpha 2 \delta-1$ subunit. J Pharmacol Exp Ther 338:240-245.

Ramirez DM and Kavalali ET (2011) Differential regulation of spontaneous and evoked neurotransmitter release at central synapses. Curr Opin Neurobiol 21: $275-282$.

Risher WC and Eroglu C (2012) Thrombospondins as key regulators of synaptogenesis in the central nervous system. Matrix Biol 31:170-177.

Risher WC, Kim N, Koh S, Choi JE, Mitev P, Spence EF, Pilaz LJ, Wang D, Feng G, Silver DL, et al. (2018) Thrombospondin receptor $\alpha 2 \delta-1$ promotes synaptogenesis and spinogenesis via postsynaptic Rac1. J Cell Biol 217:3747-3765.

Rosenmund C and Stevens CF (1996) Definition of the readily releasable pool of vesicles at hippocampal synapses. Neuron 16:1197-1207.

Salter MW and Kalia LV (2004) Src kinases: a hub for NMDA receptor regulation. Nat Rev Neurosci 5:317-328.

Salter MW and Pitcher GM (2012) Dysregulated Src upregulation of NMDA receptor activity: a common link in chronic pain and schizophrenia. FEBS $J$ 279:2-11.

Sara Y, Virmani T, Deák F, Liu X, and Kavalali ET (2005) An isolated pool of vesicles recycles at rest and drives spontaneous neurotransmission. Neuron 45:563-573. 
Schneider R, Hosy E, Kohl J, Klueva J, Choquet D, Thomas U, Voigt A, and Heine M (2015) Mobility of calcium channels in the presynaptic membrane. Neuron 86 : $672-679$.

Sengar AS, Li H, Zhang W, Leung C, Ramani AK, Saw NM, Wang Y, Tu Y, Ross PJ, Scherer SW, et al. (2019) Control of long-term synaptic potentiation and learning by alternative splicing of the NMDA receptor subunit GluN1. Cell Rep 29: 4285-4294.e5.

Singh L, Donald AE, Foster AC, Hutson PH, Iversen LL, Iversen SD, Kemp JA, Leeson PD, Marshall GR, Oles RJ, et al. (1990) Enantiomers of HA-966 (3-amino-1hydroxypyrrolid-2-one) exhibit distinct central nervous system effects: (+)-HA-966 is a selective glycine/N-methyl-D-aspartate receptor antagonist, but (-)-HA-966 is a potent gamma-butyrolactone-like sedative. Proc Natl Acad Sci USA 87:347-351.

Singh L, Field MJ, Ferris P, Hunter JC, Oles RJ, Williams RG, and Woodruff GN (1996) The antiepileptic agent gabapentin (Neurontin) possesses anxiolytic-like and antinociceptive actions that are reversed by D-serine. Psychopharmacology (Berl) 127:1-9.

Sos P, Klirova M, Novak T, Kohutova B, Horacek J, and Palenicek T (2013) Relationship of ketamine's antidepressant and psychotomimetic effects in unipolar depression. Neuroendocrinol Lett 34:287-293.

Sprosen T (1991) An electrophysiological investigation into the development and allosteric modulation of the NMDA-receptor-channel complex in rat striatum, Pharmacology, University of Cambridge, Cambridge, England.

Suárez LM, Suárez F, Del Olmo N, Ruiz M, González-Escalada JR, and Solís JM (2005) Presynaptic NMDA autoreceptors facilitate axon excitability: a new molecular target for the anticonvulsant gabapentin. Eur $J$ Neurosci 21:197-209.

Südhof TC (2017) Synaptic neurexin complexes: a molecular code for the logic of neural circuits. Cell 171:745-769.

Sun W, Larson MJ, Kiyoshi CM, Annett AJ, Stalker WA, Peng J, and Tedeschi A (2020) Gabapentinoid treatment promotes corticospinal plasticity and regeneration following murine spinal cord injury. J Clin Invest 130:345-358.

Swartzwelder HS, Park MH, and Acheson S (2017) Adolescent ethanol exposure enhances NMDA receptor-mediated currents in hippocampal neurons: reversal by gabapentin. Sci Rep 7:13133.

Takahashi DK, Jin S, and Prince DA (2018) Gabapentin prevents progressive increases in excitatory connectivity and epileptogenesis following neocortical trauma. Cereb Cortex 28:2725-2740.

Taylor CP (2009) Mechanisms of analgesia by gabapentin and pregabalin--calcium channel alpha2-delta [Cavalpha2-delta] ligands. Pain 142:13-16.

Taylor CP, Angelotti T, and Fauman E (2007) Pharmacology and mechanism of action of pregabalin: the calcium channel alpha2-delta (alpha2-delta) subunit as a target for antiepileptic drug discovery. Epilepsy Res 73:137-150.

Taylor CP and Garrido R (2008) Immunostaining of rat brain, spinal cord, sensory neurons and skeletal muscle for calcium channel alpha2-delta (alpha2-delta) type 1 protein. Neuroscience 155:510-521.

Theret L, Jeanne A, Langlois B, Hachet C, David M, Khrestchatisky M, Devy J, Hervé E, Almagro S, and Dedieu S (2017) Identification of LRP-1 as an endocytosis and recycling receptor for $\beta 1$-integrin in thyroid cancer cells. Oncotarget 8 $78614-78632$.

Tong XJ, López-Soto EJ, Li L, Liu H, Nedelcu D, Lipscombe D, Hu Z, and Kaplan JM (2017) Retrograde synaptic inhibition is mediated by $\alpha$-neurexin binding to the $\alpha 2 \delta$ subunits of N-type calcium channels. Neuron 95:326-340.e5.

Tran MD and Neary JT (2006) Purinergic signaling induces thrombospondin-1 expression in astrocytes. Proc Natl Acad Sci USA 103:9321-9326.

Traynelis SF, Wollmuth LP, McBain CJ, Menniti FS, Vance KM, Ogden KK, Hansen KB, Yuan H, Myers SJ, and Dingledine R (2010) Glutamate receptor ion channels: structure, regulation, and function. Pharmacol Rev 62:405-496.
Tuchman M, Barrett JA, Donevan S, Hedberg TG, and Taylor CP (2010) Central sensitization and $\mathrm{Ca}(\mathrm{V}) \alpha_{2} \delta$ ligands in chronic pain syndromes: pathologic processes and pharmacologic effect. $J$ Pain 11:1241-1249.

van Schalkwyk GI, Wilkinson ST, Davidson L, Silverman WK, and Sanacora G (2018) Acute psychoactive effects of intravenous ketamine during treatment of mood disorders: analysis of the Clinician Administered Dissociative State Scale. J Affect Disord 227:11-16.

Wang J, Li K-L, Shukla A, Beroun A, Ishikawa M, Huang X, Wang Y, Wang YQ, Bastola ND, Huang HH, et al. (2020) Cocaine triggers glial-mediated synaptogenesis. bioRxiv Available from: https://doi.org/10.1101/2020.01.20.896233.

Wang M, Offord J, Oxender DL, and Su T-Z (1999) Structural requirement of the calcium-channel subunit alpha2delta for gabapentin binding. Biochem $J$ 342:313-320.

Welling A, Bosse E, Cavalié A, Bottlender R, Ludwig A, Nastainczyk W, Flockerzi V, and Hofmann F (1993) Stable co-expression of calcium channel alpha 1, beta and alpha 2/delta subunits in a somatic cell line. J Physiol 471:749-765.

Woodhall G, Evans DI, Cunningham MO, and Jones RS (2001) NR2B-containing NMDA autoreceptors at synapses on entorhinal cortical neurons. $J$ Neurophysiol 86:1644-1651.

Wu J, Yan Z, Li Z, Qian X, Lu S, Dong M, Zhou Q, and Yan N (2016) Structure of the voltage-gated calcium channel $\mathrm{Ca}(\mathrm{v}) 1.1$ at $3.6 \AA$ resolution. Nature 537:191-196.

Yoon MH and Yaksh TL (1999) The effect of intrathecal gabapentin on pain behavior and hemodynamics on the formalin test in the rat. Anesth Analg 89:434-439.

Yu YP, Gong N, Kweon TD, Vo B, and Luo ZD (2018) Gabapentin prevents synaptogenesis between sensory and spinal cord neurons induced by thrombospondin4 acting on pre-synaptic $\mathrm{Ca}_{\mathrm{v}} \alpha_{2} \delta_{1}$ subunits and involving T-type $\mathrm{Ca}^{2+}$ channels. $\mathrm{Br}$ $J$ Pharmacol 175:2348-2361.

Yuan P, Leonetti MD, Pico AR, Hsiung Y, and MacKinnon R (2010) Structure of the human BK channel Ca2+-activation apparatus at 3.0 A resolution. Science 329:182-186.

Zamponi GW, Striessnig J, Koschak A, and Dolphin AC (2015) The physiology, pathology, and pharmacology of voltage-gated calcium channels and their future therapeutic potential. Pharmacol Rev 67:821-870

Zhang FX, Gadotti VM, Souza IA, Chen L, and Zamponi GW (2018) BK potassium channels suppress Cav $\alpha 2 \delta$ subunit function to reduce inflammatory and neuropathic pain. Cell Rep 22:1956-1964.

Zheng GZ, Bhatia P, Daanen J, Kolasa T, Patel M, Latshaw S, El Kouhen OF, Chang R, Uchic ME, Miller L, et al. (2005) Structure-activity relationship of triazafluorenone derivatives as potent and selective mGluR1 antagonists. $J$ Med Chem 48:7374-7388.

Zhou C and Luo ZD (2014) Electrophysiological characterization of spinal neuron sensitization by elevated calcium channel alpha-2-delta-1 subunit protein. Eur $J$ Pain 18:649-658.

Zhou C and Luo ZD (2015) Nerve injury-induced calcium channel alpha-2-delta-1 protein dysregulation leads to increased pre-synaptic excitatory input into deep dorsal horn neurons and neuropathic allodynia. Eur J Pain 19:1267-1276.

Zhou JJ, Li DP, Chen SR, Luo Y, and Pan HL (2018) The $\alpha 2 \delta-1-N M D A$ receptor coupling is essential for corticostriatal long-term potentiation and is involved in learning and memory. $J$ Biol Chem 293:19354-19364.

Zhou N, Rungta RL, Malik A, Han H, Wu DC, and MacVicar BA (2013) Regenerative glutamate release by presynaptic NMDA receptors contributes to spreading depression. J Cereb Blood Flow Metab 33:1582-1594.

Address correspondence to: Charles P. Taylor, CP Taylor Consulting, 7560 Lake Shore Dr., Chelsea, MI 48118. E-mail: taylor.charles54@gmail.com 